This item was submitted to Loughborough's Research Repository by the author.

Items in Figshare are protected by copyright, with all rights reserved, unless otherwise indicated.

\title{
The political legacies of rebel rule: Evidence from a natural experiment in Côte d'Ivoire
}

\author{
PLEASE CITE THE PUBLISHED VERSION
}

https://doi.org/10.1177/00104140211047409

\section{PUBLISHER}

Sage

VERSION

AM (Accepted Manuscript)

\section{PUBLISHER STATEMENT}

This paper was accepted for publication in the journal Comparative Political Studies and the definitive published version is available at https://doi.org/10.1177/00104140211047409. Users who receive access to an article through a repository are reminded that the article is protected by copyright and reuse is restricted to non-commercial and no derivative uses. Users may also download and save a local copy of an article accessed in an institutional repository for the user's personal reference. For permission to reuse an article, please follow our Process for Requesting Permission.

\section{LICENCE}

CC BY-NC-ND 4.0

\section{REPOSITORY RECORD}

Martin, Philip, Giulia Piccolino, and Jeremy Speight. 2022. "The Political Legacies of Rebel Rule: Evidence from a Natural Experiment in Côte D'ivoire". Loughborough University. https://hdl.handle.net/2134/15180609.v1. 


\title{
The Political Legacies of Rebel Rule: \\ Evidence from a Natural Experiment in Côte d'Ivoire
}

\author{
Philip A. Martin ${ }^{1}$ \\ Giulia Piccolino ${ }^{2}$ \\ Jeremy S. Speight ${ }^{3}$
}

\begin{abstract}
How does exposure to rebel rule affect citizens' political attitudes after armed conflicts end? We combine original survey data from Côte d'Ivoire with a natural experiment based on the arbitrary location of a ceasefire boundary to estimate the effects of exposure to rebel rule by the Forces Nouvelles (FN) on Ivorians' sense of democratic citizenship. Our findings show that individuals in communities ruled by the FN held more negative attitudes about local government institutions seven years after the reunification of the country, held weaker commitments to civic obligations, and were more likely to condone extralegal actions. The effects of rebel rule are larger than the effects of extreme lived poverty, and appear among both rebel coethnics and non-coethnics. Using qualitative and survey evidence we propose three theoretical mechanisms to explain why exposure to rebel rule weakened citizen-state relations: disrupted norms of compliance with state-like authorities, the formation of local self-help institutions leading to negative assessments of the redeployed state, and resentment due to unmet expectations of economic recovery. Our study informs debates about the links between war, citizenship, and statebuilding.
\end{abstract}

Word count: 11,669

\footnotetext{
${ }^{1}$ Assistant Professor, Schar School of Policy and Government, George Mason University.

${ }^{2}$ Senior Lecturer in Politics and International Relations, Loughborough University.

${ }^{3}$ Associate Professor, Political Science Department, University of Alaska Fairbanks.
} 


\section{Introduction}

Millions of civilians in conflict-affected countries live under the de facto control of non-state armed groups. Between 1945 and 2011, over 160 non-state armed groups exercised at least some territorial control across 62 countries in over 100 conflicts (Cunningham, Gleditsch and Salehyan 2013). Despite a surge of scholarly interest in "rebel rulers" (Arjona, Kasfir and Mampilly 2015), however, little is known about how insurgent control shapes the social and political attitudes of civilians. There is particularly little evidence about how rebel rule shapes citizen-state relations in postwar democratic contexts.

This article investigates how local exposure to territorial control by a non-state armed group ("rebel rule") impacts citizens' attitudes towards post-conflict government institutions and civic obligations. Restoring civilian confidence in state structures and democratic processes is widely recognized as a central challenge of post-conflict reconstruction and peacebuilding (Paris and Sisk 2009), yet existing research offers little consensus about whether and how wartime experiences of rebel rule might shape such post-conflict dynamics. According to one view, exposure to political control by non-state armed groups can catalyze greater political participation and engagement among civilians by triggering processes of mobilization (Wood 2003; Huang 2016). Other research, meanwhile, suggests that exposure to rebel rule and rebel service provision can erode trust and the state-citizen social contract (Kubota 2017; Kubota 2018). Systematic evidence to scrutinize these seemingly conflicting claims is lacking.

Isolating the impact of rebel rule on civilian attitudes presents two main challenges. First, one requires fine-grained survey data not only from areas exposed to rebel rule, but also comparable areas not exposed to rebel rule. Second, rebel rule is not, in general, randomly

assigned. Insurgents conquer, hold, and govern some areas and not others for reasons of 
both strategy and opportunity. If we ignore this type of confounding and simply compare outcomes in former rebel- and government- controlled areas, we risk introducing bias.

In this paper, we address both issues by leveraging data from an original survey in Côte d'Ivoire that permits us to evaluate civilians' political attitudes in former rebel- and government-controlled areas that are highly comparable. Our strategy is based on the arbitrary placement of a ceasefire boundary during the Ivorian armed conflict (2002-2011). We show that the exact location of the partition line in several regions of western Côte d'Ivoire was an artefact of the timing of military mobilization by Ivorian rebels and French interposition forces, and not the prewar characteristics of local communities. We then compare individuals in communities that fell "just inside" the rebel-occupied zone from 2002 to 2011 with those in very similar communities that fell "just outside" and remained under government control. Importantly, Côte d'Ivoire represents a typical case of rebel rule in a contemporary civil war: a non-state armed group seized de facto control over territory in a peripheral region, ruled civilians for several years through a mixture of direct governance and local power-sharing, and then demobilized and integrated into a unified postwar state. Côte d'Ivoire thus marks a highly relevant case for understanding citizen-state relations in the aftermath of rebel rule.

We analyze respondent attitudes that pertain to a key element of citizen-state relations: individuals' sense of "democratic citizenship." Democratic citizenship refers to a cluster of views held by citizens about the political community to which they nominally belong, including both confidence in government institutions as well as the inclination to perform actions that might influence decision-making (Verba and Nie 1987; Hoskins and Mascherini 2009). These kinds of citizen attitudes figure prominently in scholarly accounts of postconflict statebuilding (Karim 2020), and are a focal point for peacebuilding programs in many fragile states (Paffenholz and Spurk 2006). We assess three clusters of indicators to capture views about democratic citizenship in post-conflict Côte d'Ivoire: confidence in local 
state institutions, views about civic obligations, and attitudes about extralegal actions.

Our central finding is that exposure to rebel rule had lasting, statistically significant, and substantively meaningful negative effects on Ivorians' attitudes regarding democratic citizenship. We find that respondents in communities that fell under rebel control experience a decrease in favorable attitudes about local state institutions like the police and municipal government, and an increase in their willingness to condone anti-state actions such as refusing to pay taxes. Exposure to rebel rule also reduced respondents' sense of civic duties, such as the duty to vote in elections. These findings are especially striking given the political context of postwar Côte d'Ivoire: the regime that has controlled the country since 2011 is widely perceived as a "government of Northerners," sympathetic to the former constituency of the rebellion (Piccolino 2018).

What explains the apparent negative effects of exposure to rebel rule on Ivorians' relationship with the postwar state? We present suggestive evidence for three mechanisms (two of which are drawn from the existing literature, and one that we formulated inductively). First, rebel rule may have disrupted Ivorians' "habitual" compliance with the state. Prior norms of obedience to formal institutions were weakened as a result of being cut off from official state authorities for nine years, which in turn diminished the perceived obligation to perform civic duties associated with the state. Second, rebel rule spurred civilian collective action and the development of new systems of goods provision independent from the state. These localized forms of community solidarity persisted after national re-unification, and in turn "crowded out" redeployed state authorities in former rebel zones. Finally, we observed that Ivorians in rebel-ruled areas experienced frustration with the post-conflict state because they felt that they had not had benefited economically since the end of the conflict, despite their wartime hardships. Together, these mechanisms eroded rebel-ruled populations' perceptions of the relative efficacy of formal and extra-local governance authorities, an attitudinal shift that persists to this day. 
Our study makes several contributions to the research program on the political legacies of conflict. First, we add to the literature on rebel governance. While past studies on rebel control of civilians are empirically rich, the literature on the individual-level legacies of rebel rule remains embryonic (but see Bakke et al. 2014; Huang 2016; Kubota 2017; 2018; Albert 2020). This study leverages a rare natural experiment that sheds light on the political consequences of insurgent control of civilians. Overall, our findings highlight the potential limits of claims that rebel governance strengthens post-conflict state-society relationships.

Second, we contribute to the debate on armed conflict and political engagement. Whereas past research has been dominated by a focus on violence and victimization (Bauer et al. 2016; Freitag, Kijewski and Oppold 2017; Blattman 2009), our study emphasizes a broader set of wartime experiences that can have enduring social and political effects (Wood 2008; 2015). Finally, our study responds to the call from scholars for greater attention to the nexus between armed conflict and institutions, and in particular the mechanisms that connect civil war to the (re)construction of citizen-state relationships (Arjona 2014). By documenting the direction and magnitude of the effects of exposure to rebel rule on civilian attitudes about democratic citizenship, our study illustrates how conflict processes can hinder statebuilding in postwar democracies.

\section{Motivation \& Theory}

Does exposure to rebel rule affect civilians' political attitudes - specifically, their attitudes concerning democratic citizenship - after formerly rebel-occupied communities are reintegrated into a unified postwar polity? If so, will the legacies of rebel rule foster increased citizen engagement in the formal political arena, or have the opposite effect? In line with previous work, we define rebel rule as a situation where a non-state armed organization exercises de facto control over the conduct of civilians and the provision of basic goods in a 
territory that is under the de jure authority of a recognized sovereign state (Arjona, Kasfir and Mampilly 2015, 1-3).

A rich literature examines the practices of social and political control that insurgents employ to govern civilians in rebel-ruled areas, and the varied motives behind these governance practices. While some rebel groups provide essentially no goods or security to civilians (Reno 1999), most armed groups engage in governance in at least some domains of civilian life in an effort to create an alternative order and garner local support (Arjona 2016; Huang 2016). In cases where rebels take steps to preserve social order, they can engage civilians in different ways. Armed groups vary, for instance, in terms of whether they integrate non-combatants into wartime governance through local power-sharing arrangements, and whether they provide services to civilians, such as education, health care, dispute resolution, and policing (Mampilly 2011; Huang 2016; Stewart 2018; Mampilly and Stewart 2021). Variation in the scope and quality of rebel governance may be shaped by, among other factors, strategic dynamics (Kasfir 2005; Kalyvas 2006), ideology (Stewart 2018), the strength of community organizations (Péclard and Mechoulan 2015; Arjona 2016; van Baalen 2021), and rebel access to material resources (Weinstein 2006; Huang 2016).

Though this literature is impressive, evidence about the post-conflict legacies of rebel rule among civilians remains thin. Most research on the individual-level legacies of conflict focuses narrowly on the effects of victimization and exposure to violence, rather than exposure to political control by non-state armed groups. For instance, important research has studied how violence influences social capital and trust between citizens (Collier et al. 2003; Bauer et al. 2016), citizen attitudes towards the state (Bakke et al. 2014; De Juan and Pierskalla 2016) and political participation after violent conflict (Blattman 2009; Freitag, Kijewski and Oppold 2017). Perhaps counter-intuitively, much of this literature suggests that exposure to conflict can prompt cooperation and citizen engagement in political life after civil war (Blattman 2009; Voors et al. 2012; Bauer et al. 2016; Freitag, Kijewski and Oppold 2017). 
By contrast, other studies find that exposure to wartime traumas tend to weaken trust and associational membership (De Juan and Pierskalla 2016; De Luca and Verpoorten 2015; Cassar, Grosjean and Whitt 2013). Yet the effects of non-violent conflict processes related to rebel rule have received less attention.

Moreover, the literature that does exist on the political legacies of rebel rule has yielded mixed findings. Some studies suggest that local interactions with non-state armed groups can boost postwar political engagement among civilians, a process we term the mobilization mechanism. Wood (2003) and Huang (2016), for example, argue that rebel-civilian interactions can increase the likelihood of active citizenship and post-war democratization. Whether instigated by rebel rulers - via rallies, persuasion, or other tactics - or by civilians who autonomously organize for self-protection, mobilization of civilians in rebel-ruled areas may create heightened political awareness and habits of political participation, which in turn persist into the post-conflict period and lead citizens to proactively engage with post-conflict state institutions. Viewed in this light, exposure to rebel rule may resemble other types of conflict-related experiences, such as witnessing violence or experiencing crime, that can cause individuals to become politically "activated" (Blattman 2009).

Other work, however, suggests that exposure to rebel rule may have the opposite consequences for democratic citizenship. One such perspective arises from the literature on norms of citizen compliance. In this view, perceptions of the legitimacy and appropriateness of governing institutions - and corresponding duties to those institutions - emerge in part from a process of "mechanical ascription," wherein long-term territorial control creates "robust informational monopolies that socialize populations accordingly" (Kalyvas 2006, 125). Many citizens may cooperate with state authorities as a "natural" course of action, reinforcing local norms that state authorities deserve respect and that formal civic duties ought to be followed (Dreier and Lake 2019). Following this understanding of citizen-state relations, exposure to rebel rule and the attendant rupture in state sovereignty may serve as a kind 


\begin{tabular}{c|c} 
Mechanism & Expected Direction of Effect \\
\hline Mobilization & + \\
Disrupted norms of compliance & - \\
Rival governance & -
\end{tabular}

Table 1: Rebel Rule and Postwar Democratic Citizenship: Theoretical Mechanisms

of exogenous shock for civilians that "breaks" long-held habits of compliance with the state and citizenship duties associated with formal government structures. This disrupted norms of compliance mechanism may be most likely in areas where insurgents govern arbitrarily or fail to recreate predictable "state-like" institutions.

Rebel rule can also create space for the construction of enduring forms of social solidarity and non-state governance that may later rival the post-conflict state, potentially further weakening democratic citizenship. For example, Kubota (2017) argues that governance by the Liberation Tigers of Tamil Eelan (LTTE) in Sri Lanka supplanted and co-opted state institutions, creating impediments to the post-conflict reconstitution of citizen trust and identification with the government. Martin, Piccolino and Speight (2021a) similarly found that many rebel-occupied communities in Côte d'Ivoire continued to rely on ex-rebel actors for informal services and protection, crowding out the role of redeployed police forces. Rebel rule can also bolster community-based institutions and patterns of local collective action in response to service shortfalls (Mampilly 2011; Barter 2016; Wood 2008). In contrast to the mobilization mechanism, however, such practices of community solidarity may ironically reinforce opposition to and distrust of external governance authorities (cf Arjona 2016) after war's end if citizens evaluate postwar redeployed state institutions negatively relative to local self-help alternatives. If redeployed state authorities in former rebel-ruled areas are unable to convincingly (re)claim status as the primary guarantors of social order and essential goods, they may struggle to build popular legitimacy and restore the citizen-state social contract (Bakke et al. 2014; Bakke et al. 2018; Schmelzle and Stollenwerk 2018, 464). We call this the rival governance mechanism. 
Overall, the existing literature remains ambiguous about which of these mechanisms is likely to be most salient, and therefore whether local exposure to rebel rule is likely to strengthen or weaken post-conflict democratic citizenship in the aggregate. In part, this ambiguity can be traced to issues of methodology. Previous studies have rarely employed research designs that permit confident causal inferences about the post-war effects of rebel rule. While there are now a handful of studies that draw on fine-grained survey evidence (Bakke et al. 2014; Bakke et al. 2018; Kubota 2017; Kubota 2018), this work has not compared outcomes in areas ruled by armed movements to plausible counterfactuals, e.g. otherwise similar areas that remained under sovereign government control. Moreover, because rebel rule is not randomly assigned across territory, it is difficult to distinguish between the effects of rebel rule and other confounding factors that may influence the choice of rebels to conquer and rule particular areas. For instance, if latent receptivity to rebels among the civilian population is also correlated with pro-civic attitudes - for whatever reason - then the estimated impact of rebel rule on postwar civic attitudes may appear positive even if the average causal effect is actually negative. Our study attempts to address this issue headon. Crucially, and in contrast to past observational studies, we leverage a unique natural experiment that allows us to isolate the effects of rebel rule from other confounding factors.

A second possible reason for the ambiguity of the existing literature is that there is a good deal of variation in the nature of governance arrangements introduced by armed movements, as well as political dynamics across post-conflict environments. For instance, local exposure to rule by rebel groups that engage in extensive institution-building and ideological mass mobilization (as with some Marxist-Leninist insurgencies) may yield different patterns of citizen political engagement than exposure to ethno-nationalist rebellions or groups without clear political aims (Huang 2016, 90-102). ${ }^{1}$ Moreover, exposure to rebel rule in civil wars ending in decisive rebel victories may generate stronger attitudes of democratic citizenship

\footnotetext{
${ }^{1}$ Although Blattman (2009) finds evidence of the mobilization mechanism among former members of the Lord's Resistance Army in Uganda, suggesting that this mechanism may apply quite broadly.
} 
than those ending in negotiated settlements or rebel defeat, if habits of participation in rebel governance structures are transfered to the post-conflict state. ${ }^{2}$

These distinctions lead us to add important qualifiers to our study. First, as described below, our findings from Côte d'Ivoire likely pertain most closely to cases of "status quo" rebel rule (Mampilly and Stewart 2021), where rebels provide core public goods but do not attempt to revolutionize existing social or political relations in society. Second, we study the legacies of rebel rule in a post-conflict context where the challenger armed group succeeded in deposing the incumbent regime and integrating into the state. Thus, if exposure to rebel rule in fact enhances democratic citizenship via the mobilization mechanism, we would expect to be able to detect such positive effects in our research setting.

\section{Rebel Rule in the Ivorian Context}

Rebel rule emerged in northern Côte d'Ivoire following the onset of civil war on September 19, 2002 when a group of Ivorian military officers, of mainly northern descent, attempted to overthrow the southern-based government of Laurent Gbagbo (Akindès 2004). Although the mutineers failed to capture Abidjan, they quickly seized control in northern towns and cities under the aegis of the Patriotic Movement of Côte d'Ivoire (MPCI). Two additional rebel groups, the Ivorian Popular Movement for the Great West (MPIGO) and the Movement for Justice and Peace (MJP) emerged in the west of the country in November 2002. By January 2003, these rebel factions formally unified to become the Forces Nouvelles (FN). Côte d'Ivoire remained territorially partitioned until 2011, when FN military forces removed Gbagbo from power and installed the FN-supported political candidate, Alassane Ouattara. Insurgent forces integrated into the new national army and the FN administration in the north was

\footnotetext{
${ }^{2}$ The contrasting findings of Kubota (2017) and Wood (2003) may stem in part from such case-specific differences.
} 
dismantled as Ouattara redeployed state institutions throughout the country (Fofana 2011). The Ivorian post-war government is widely seen as sympathetic to the former constituencies of the FN, and Ouattara's Rally of Houphouëtists for Democracy and Peace (RHDP) party ${ }^{3}$ enjoys strong electoral support in former rebel-controlled areas (Piccolino 2018)

How did FN rebels rule civilians during the Ivorian conflict? Between 2002 and 2011, the FN occupation deprived millions of civilians from access to public services and caused significant social and economic disruption. While large-scale battles were rare, and the presence of international peacekeepers meant that populations in the rebel zone did not experience extensive state violence, local political order initially collapsed. State security personnel either joined the FN or fled, precipitating widespread looting and property damage. The Gbagbo government ordered civil servants to leave the north, and threatened to sack officials who did not comply (Hamer 2007). Most government bureaucrats, teachers and medical professionals soon fled the rebel zone.

Initial efforts at governing FN-controlled territory involved the creation of ten administrative zones. Each zone was managed by a military commander - popularly referred to as com'zones. These zone commanders used their wartime positions to gain wealth by taxing economic activity, controlling illicit resource extraction, and operating a ubiquitous network of rebel-operated checkpoints that created increased frustration among civilians as the conflict wore on (Bassett 2011). Aware that complaints about living conditions in the north threatened the FN's legitimacy, rebel leaders took steps beginning in 2003 to develop additional institutional structures to restore a sense of normalcy and order (Heitz 2009; Popineau 2017; Förster 2015). The FN leadership created a civilian-staffed General Secretariat, headed by Guillaume Soro, which was responsible for social and political affairs. The Secretariat was represented by délégations générales in each of the ten administrative zones (Fofana 2012). To centralize control over rebel finances, the FN created a body called

\footnotetext{
${ }^{3}$ The RHDP was created as a unitary party in 2018 by merging the previous Rally of the Republicans (RDR) with other smaller political factions.
} 
La Centrale Economique. These institutions helped the FN to project an image - however selective in presentation - of running a "state-like" administration complete with official stamps, transportation permits, and birth certificates.

Crucially, the FN often relied heavily on collaborations with existing community leaders and organizations in rebel-ruled territory, both to shore up their own legitimacy and ensure civilian access to basic goods and services (Heitz 2009, Fofana 2012). Healthcare, for example, was mainly provided by international humanitarian organizations, sometimes in cooperation with local NGOs or medical personnel who remained in the area. To meet demands for schooling and education, voluntary teachers' initiatives emerged throughout the rebel-occupied zone (Popineau 2017; Hamer 2007). In the security domain, the FN usually retained the most important role, but commanders occasionally brokered arrangements with local dozo hunting associations, who acted as informal deputized police forces and enjoyed significant autonomy from the rebel command structure (Förster 2015, 213-216). Towards the terminal stages of the conflict, the FN also collaborated with government prefects who began to return to their offices in the north in 2009, though these officials typically lacked any real authority relative to the $\mathrm{FN}$ com'zones.

In many respects, then, the FN represent a "typical case" of contemporary rebel rule. As with many territorial non-state armed groups, the FN provided security and collected taxes, but did not intervene in all aspects of civilian life. This pattern is common: Huang (2016, 72), for instance, shows that rebels engaged in extensive institution-building in only 13 percent of armed conflicts occurring between 1950 and 2006. And similar to other rebellions in countries with a history of weak state penetration into society, where the prewar state bureaucracy coexisted with alternative governance providers, FN rebels had to negotiate their rule with a multiplicity of existing local actors, such as village chiefs, traditional hunters and religious leaders (Mampilly 2011). Overall, while local variations in the quality of political order, service access, and civilian victimization existed (which we explore further 
below) rebel governance of civilians in FN territory from 2002 to 2011 is best conceptualized as what Mampilly and Stewart $(2021,16-20)$ refer to as the "status quo" mode of rebel political control. Like other rebels in this category (such as the Eritrea Liberation Front or the Gerakan Aceh Merdekafree), the FN shared power with some local elites and co-opted existing institutions in order to administer civilians more efficiently, while refraining from extensive governance innovation or radical efforts to make political life more inclusive for civilians.

\section{Research Design}

To estimate the effects of local exposure to rebel rule on Ivorians' political attitudes, we leverage the arbitrary placement of a ceasefire boundary that separated rebel and governmentcontrolled zones in the center-west and western regions of Côte d'Ivoire, running from Bouaké to Zouan-Hounien near the Liberian border. The northern side of this boundary was ruled by the FN, while the southern side remained under the control of the Gbagbo administration (Figure 1). The ceasefire line constituted a "solid" boundary on the rebel zone, beyond which FN forces did not operate. Our empirical strategy hinges on the fact that several regions in this zone - Gbêkê, Marahoué, Haut-Sassandra, Guémon, and Tonkpi - were partitioned into rebel- and government-controlled zones between 2002 and 2011 in a way that was arbitrary. The as-if random nature of the partition line location allows us to escape the selection bias problem caused by rebel groups choosing territory to occupy based on the attributes of local populations, and builds on the established practice of using arbitrary jurisdictional boundaries as the basis for causal inference (Dunning 2008; McCauley and Posner 2015). 
Figure 1: Wartime Territorial Control in Côte d'Ivoire

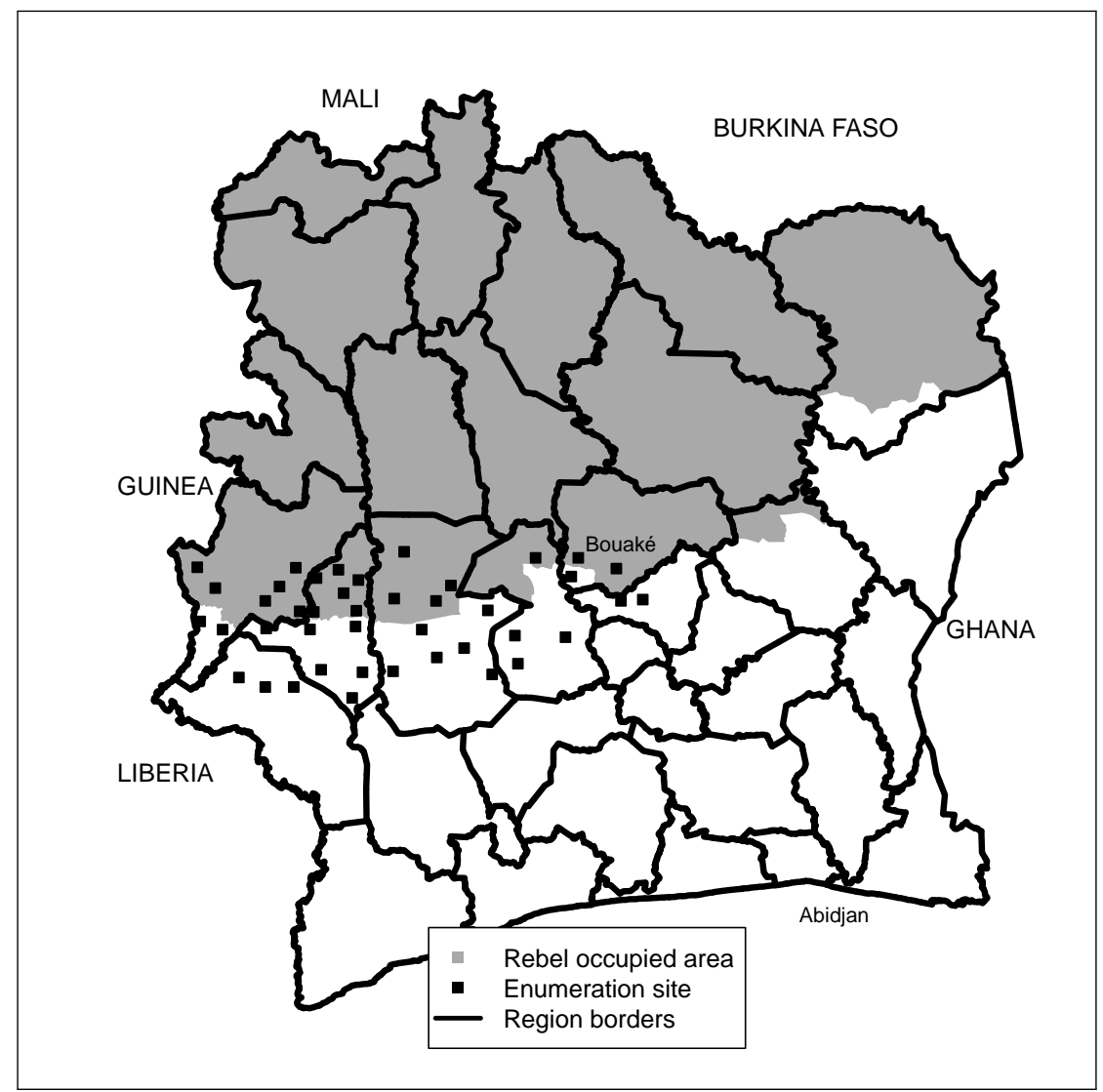

Table 2: Placebo Tests

\begin{tabular}{lcccccccc}
\hline \hline & \multicolumn{7}{c}{ Dependent variable: } \\
\cline { 2 - 8 } & Education & Poverty & Mande & Akan & Krou & Christian & Female & Years \\
& $(1)$ & $(2)$ & $(3)$ & $(4)$ & $(5)$ & $(6)$ & $(7)$ & $(8)$ \\
\hline Treatment & -0.080 & -0.086 & 0.122 & -0.078 & 0.136 & 0.069 & 0.000 & 2.321 \\
& $(0.148)$ & $(0.079)$ & $(0.080)$ & $(0.060)$ & $(0.093)$ & $(0.055)$ & $(0.037)$ & $(1.663)$ \\
Constant & $0.864^{* * *}$ & $0.548^{* * *}$ & $0.264^{* * *}$ & $0.214^{* * *}$ & $0.200^{* * *}$ & $0.471^{* * *}$ & $0.500^{* * *}$ & $21.929^{* * *}$ \\
& $(0.128)$ & $(0.066)$ & $(0.032)$ & $(0.041)$ & $(0.043)$ & $(0.037)$ & $(0.025)$ & $(0.878)$ \\
$\mathrm{N}$ & 500 & 500 & 500 & 500 & 500 & 500 & 500 & 500 \\
\hline
\end{tabular}

Notes: OLS regression estimates (cluster-robust standard errors in parentheses) of placebo outcomes of rebel rule. Outcomes are department-level measures of education and poverty in May 2002, demographic indicators for ethnicity, religion, female, and the number of years lived in the enumeration area site locality. ${ }^{*} \mathrm{p}<0.1 ;{ }^{* *} \mathrm{p}<0.05 ;{ }^{* * *} \mathrm{p}<0.01$ 
The key determinant of the ceasefire boundary location in our area of focus was the timing of French and rebel military mobilization in the early stages of the 2002 rebellion. Initially, the French government was reluctant to intervene in its former colony, but the mutineers' rapid capture of northern territory shocked French leaders into action. Realizing that the rebels might overwhelm Gbagbo's government and destabilize the country, France mobilized military forces stationed in Abidjan and Gabon at the end of September to prevent escalating violence (Charbonneau 2012). The French interposition force - known as Operation Licorne - halted the southward advance of MPCI/FN units, resulting in clashes between French and rebel forces (Chelpi-den Hamer 2011). A small number of troops from the Economic Community of the West African States (ECOWAS) also deployed at the end of 2002 to reinforce the peacekeeping presence along the frontline.

We focus on the western portion of the ceasefire line, and not the east, because the MPCI/FN's military offensives in the fall of 2002 were concentrated on capturing this strategically important area (due to the production and shipping of cocoa), yet were only partially successful. East of Bouaké, rebels made few attempts to expand beyond the northern strongholds that had offered limited initial resistance, resulting in a territorial partition that was decidedly non-random. ${ }^{4}$ In the center- and far-west, by contrast, despite the conclusion of an initial ceasefire agreement between the rebels and the Ivorian government in October, the MPCI/FN made renewed offensives that prolonged fighting through the fall of 2002 . The FN sought to move southward as far as San Pédro on the Atlantic coast in order to deny the Gbagbo government control over the cocoa-growing southwest, even though rebel leaders anticipated that southwestern communities were likely to offer resistance (Smith 2002; International Crisis Group 2003, 20-21; phone interview with French military officer, 1 June 2010; interview with French military officer, 18 May 2010). In pushing further south, the rebels took advantage of the disorganization of the Ivorian national army, which was in chaos

\footnotetext{
${ }^{4}$ Moreover, the north-eastern region that fell under FN control has a low population density and is partly occupied by the large national park of Comoé, which would cause practical difficulties implementing a survey in areas adjacent to the ceasefire border.
} 
in the early phases of the war. What ultimately stopped the MPCI/FN offensive was the French intervention, which had reached a force of 3,800 strong by December (Charbonneau 2012, 513; Sciolino 2002). After a second ceasefire in May 2003, the ligne de font stabilized permanently, cleaving through existing administrative boundaries and effectively partitioning in half the entire districts of Montagnes and Sassandra-Marahoué. Further details on the spatial-temporal expansion of the rebel frontline appear in Appendix A.

In the end, the exact placement of the ceasefire line that spanned central and western Côte d'Ivoire was not a predetermined consequence of local demography, geography, or existing administrative boundaries - any of which could bias our study. The FN ended up in control of many ethnically inter-mixed localities where civilians expressed strong initial antipathy towards the rebel presence (Heitz 2009). ${ }^{5}$ If the timing or scale of the French military deployment had been different, or if the rebel offensive had progressed slower or faster even by several days - the FN might have been stopped another 100km to the north (and thereby failed to seize the cities of Man, Vavoua or Sakassou), or they might have advanced another 100km south (and seized the cities of Daloa and Duekoué, for example). For many communities located close to the ceasefire line, therefore, "assignment" to exposure to the FN occupation essentially amounted to a coin-flip.

But how can we be confident that communities that were slightly farther north (and thus fell under rebel control) are not different in some way? To address this concern, we conduct a large number of placebo tests. Table 2 shows the estimates from ordinary least squares (OLS) regressions with standard errors clustered by enumeration-area of several pre-treatment and fixed covariates on a binary indicator of placement in former FN-controlled territory. We

\footnotetext{
${ }^{5}$ Historically, the politics of western Côte d'Ivoire has been shaped by the expansion of cocoa production in the 19th and 20th centuries, which triggered an influx of migrants from elsewhere in Côte d'Ivoire and West Africa (Boone 2014, 129-139). As a result, communities in these regions are characterized by a high degree of ethnic heterogeneity (the largest groups being the Mande, Krou, and Akan), as well as a history of inter-communal tensions over land access rights. Given the area's mixed demography and relatively high population density, the "Far West" has been an important site of political competition among Côte d'Ivoire's national political parties (Chauveau 2000; Allouche and Bley 2017).
} 
find that for the placebo outcomes - including department-level education and poverty levels in 2002, individual ethnicity (Mande, Akan, or Krou), Christian, female, and years lived in the sub-prefecture - the effects are not statistically distinguishable from zero. In Table A2 we also show pre-treatment balance across additional geographic and political variables including soil quality, cocoa production, annual precipitation, vote share for Ouattara's RDR party in 2001 municipal elections, and pre-ceasefire violent events.

Importantly, the fact that there is no significant difference in the number of years that respondents lived in their enumeration sites in treated and control areas allays concerns about bias resulting from population displacement or migration across the ceasefire line. Population displacements occurred in both rebel and government controlled zones, with significant IDP settlement occurring in Guiglo, Yamoussoukro, and Abidjan. ${ }^{6}$ The majority of IDPs, however, stayed with extended family and were likely to remain within their communities of origin, rather than relocate to other localities (Internal Displacement Monitoring Centre 2012, 4). Moreover, we do not find clear evidence of "sorting effects" in our sample around the ceasefire line that would introduce bias. In Table A3, we show that within the Krou, Mande, and Akan subsets in our sample, treatment status has no significant correlation with past migration, suggesting that cross-border migration did not "balance out" across groups. ${ }^{7}$

We also anticipate the concern that FN rule in these "near-border" regions may have differed from the rest of the FN zone. Evidence from our respondent survey (Table A5) indicates that Ivorians in near-border rebel areas were more likely to report being victims of violence, and were more likely to report that international peacekeeping forces visited their community between 2002 and 2011. This is unsurprising, given that the western zone particularly Tonkpi/Montagnes - was a locus of partisan violence during the Ivorian conflict (Balcells 2017; Allouche and Bley 2017). However, we find that the prevalence of permanent

\footnotetext{
${ }^{6}$ Estimates of the number of Internally Displaced Peoples in Côte d'Ivoire range from 500,000 to 750,000 (Martone 2003; Global IDP Project 2005, 11).

${ }^{7}$ We also show that our main results remain unchanged when we constrain the sample to respondents who reported living in the same locality for 8 and 16 years, respectively. See Table A4.
} 
FN camps and perceptions of the quality of wartime education and health services were quite similar in ceasefire line-adjacent communities compared to the rest of the FN zone. We also cross-check data from a separate survey of community elites in former FN localities (Table A6). Our near-border areas of focus are not anomalous in terms of whether FN rebels recruited locally, whether FN commanders held public meetings in the community, whether community elites actively supported and FN, the degree of FN involvement in service provision, or the prevalence of rebel taxation.

\section{Survey}

In order to assess the political impacts of FN rule, we partnered with the United States Agency for International Development (USAID) to implement a survey in conflict-affected areas of western, northern, and central Côte d'Ivoire in August-September 2018. ${ }^{8}$ The sampling frame consisted of all sub-prefectures that fell on the northern side of the ceasefire line (i.e. under FN control from 2002-2011), as well as sub-prefectures from an additional five regions near the ceasefire border that remained fully or partially under government control. The survey reached a total of 1200 respondents, with 300 coming from the governmentcontrolled zone. Consistent with the standard Afrobarometer sampling methodology in Côte d'Ivoire, respondents were polled proportionally to the population size of the sub-prefecture or commune. All interviews were conducted face-to-face with tablets, with specific households selected via a grid-based random-walk method. For the main analysis below, we focus on the subset of 500 respondents in treated and control enumeration areas located close to the ceasefire border (less than 100km).

\footnotetext{
${ }^{8}$ Additional details on survey methodology and a link to the survey instrument appear in Appendix B.
} 


\section{Outcome Measures}

To tap into the concept of post-conflict democratic citizenship, we assess three sets of indicators. The first set of outcomes measure respondents' confidence in the local institutions of the Ivorian state. We asked respondents whether they believed that the following institutions play a positive role in their community $(1=$ yes, $0=$ no): the prefectoral corps, the police and gendarmerie, and the local municipal government. Second, we measured respondents' attitudes about their civic obligations and duties vis-a-vis the national political community. We asked respondents if they agree that paying taxes is something that a good citizen should always do, and if they agree that citizens have a duty to vote in elections (1 $=$ yes, $0=$ no). We also asked if respondents agree that citizens should organize with other community members to demand improved government service, contact the media to call attention to poor services, or contact a government official to complain. Finally, we measured attitudes about several illegal citizen protest actions, including whether respondents agree that it is acceptable for citizens to refuse to pay taxes, establish a road block, or occupy a public building. All of our questions build on standard polling instruments in the region, such as the Afrobarometer, and are adapted to the Ivorian case. We analyze indicators individually and construct a number of summary indices.

\section{Treatment}

To measure exposure to rebel rule, we use a binary indicator of whether the enumeration area was located on the northern side of the ceasefire line. Since the ligne de front was fixed and internationally monitored, populations south of this boundary should not have been exposed to FN control. To geolocate the ceasefire boundary, we relied on maps provided by the National Institute of Statistics in Abidjan. 


\section{Modelling Choices}

To estimate the effects of the FN occupation, we use ordinary least squares (OLS) models that regress each outcome on our binary treatment indicator. ${ }^{9}$ Below, we show a simple comparison between respondents in treatment and control areas. In the Online Appendix, we show models controlling for many additional covariates. We cluster standard errors by enumeration area.

\section{Results}

Figure 2 presents the estimated effects of rebel rule on each set of outcomes, using simple bivariate regressions. The bold confidence intervals show the impact of exposure on an aggregated index of each set of outcomes. Overall, we find that compared to respondents in areas on the government side of the ceasefire line, respondents in (formerly) rebel-ruled communities are significantly less likely to view local government institutions in a positive manner $(p<0.01)$, hold weaker attitudes about civic obligations and duties $(p<0.001)$, and are more likely to view illegal "anti-state" actions as acceptable $(p<0.001)$. Appendix Figure A2 shows that including covariates in the models yields highly similar results.

Considering the outcomes separately, we see that each set of outcomes tends to move together in the same direction, adding confidence in the validity of the summary indices. Regarding attitudes about local state institutions, the point estimate of $-0.20(p<0.01)$ for "Municipal government" indicates that exposure to rebel rule results in a 20 percent decrease in the probability that respondents agree that the municipal government plays a positive role in their community. Exposure to rebel rule also results in more negative

\footnotetext{
${ }^{9}$ Replication data and code available at Martin, Piccolino and Speight (2021b)
} 
Figure 2: Estimated Impacts of Rebel Rule (OLS)
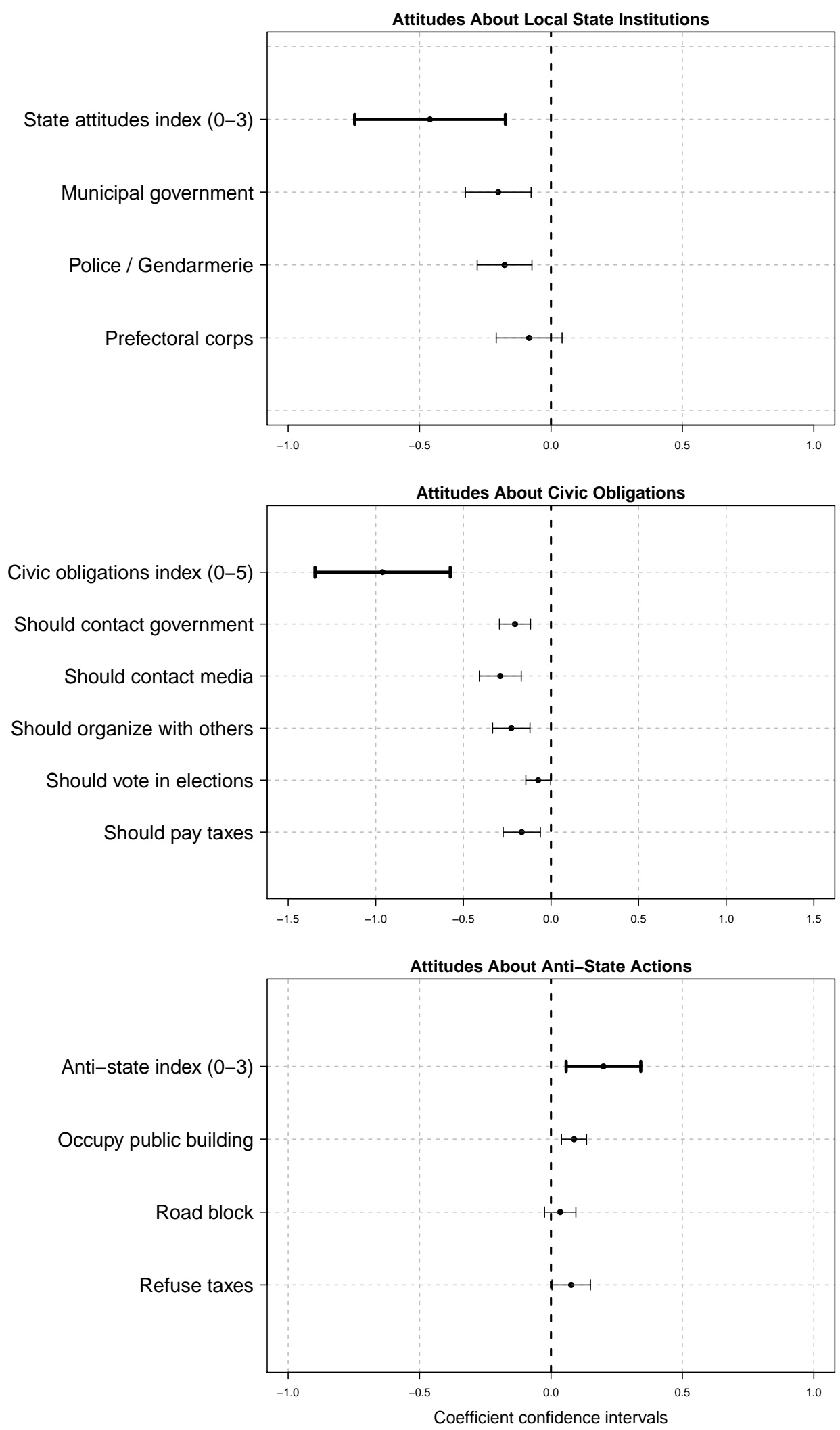

Notes: Lines show 95 per cent confidence intervals. Cluster-robust standard errors calculated at the enumeration area level. 
views towards the police (point estimate: $-0.18, p<0.01$ ). The estimated effect on views towards the prefectoral corps is negative but not statistically significant (point estimate: $-.08, p=0.19)$.

The estimated coefficients for respondents' attitudes about civic obligations show that the FN occupation had a clear negative effect. Exposure to rebel rule reduced the probability that respondents agreed that citizens should vote in elections (point estimate: $-0.07, p<0.05$ ) and pay taxes (point estimate: $-0.17, p<0.001$ ). Exposure also resulted in a 22 percent decrease $(p<0.001)$ in the probability that respondents agree that citizens should contact a government official to address governance problems, a 29 percent decrease $(p<0.001)$ in the probability of agreeing that citizens should contact the media about governance problems, and a 21 percent decrease $(p<0.001)$ in the probability of agreeing that it is appropriate to organize with others to demand improved government service.

At the same time, exposure to FN rule had a positive effect on respondents' attitudes towards the acceptability of extralegal "anti-state" actions. Treatment resulted in an increased probability that respondents agree it is appropriate to occupy a public building (point estimate: $0.09, p<0.001$ ), and refuse to pay taxes (point estimate: $0.08, p<0.01$ ). However, we do not see a clear difference in respondents' attitudes about establishing a road block (point estimate: $0.04, p=0.25)$,

How substantively important are these results? To benchmark our findings, we compare the magnitude of the estimated effects of exposure to rebel rule to the estimated effects of respondents having experienced extreme poverty in their lifetime, a socioeconomic trait that correlates strongly with our outcome measures. Table A7 shows that for the index of attitudes about local government institutions, the 0.45 unit negative effect of rebel rule is more than twice as large as the effect of a respondent having lived in extreme poverty. For attitudes about civic obligations, the negative effect of rebel rule on the summary index is 
more than three times as large as extreme lived poverty.

\section{Robustness}

We conduct a series of tests to address lingering concerns about unobserved differences between areas that fell on the FN side of the ceasefire line versus areas that remained under government control, which could introduce bias. First, we look for potential prewar differences in local social capital, which could affect both the quality of wartime governance as well as current trust in institutions. To construct proxy measures of prewar social capital, we use fine-grained data from the 2002 household quality-of-life (ENV) survey, aggregated at the department level. Specifically, we measure the proportion of households that reported receiving financial support from a community organization in the last twelve months, the proportion of households that received a loan from a neighbor or community group to cope with financial distress, and the proportion of households that were willing to accept an adopted non-familial child in crisis. None of these measures of prewar social capital differ significantly across treatment and control areas (see Table A8). Second, we constrain the sample to enumeration areas located within varied distances of the ceasefire line. If there are unobserved differences in our sample correlated with geographic location, the estimated effects of the treatment should vary between respondents in areas that are immediately adjacent to the ceasefire line and those at a near distance. Tables A9, A10, and A11 show that the estimated effects of rebel rule are quite consistent when constraining the sample in $20 \mathrm{~km}$ increments. Third, we ran our analysis using "placebo borders" at varied intervals moving north from the actual ceasefire line location. Table A12 shows that rebel-government

borders at different locations do not return significant results. Fourth, Table A13 shows that respondents' political attitudes in both the rebel and government zones are largely unrelated to the distance to the ceasefire line. Finally, we estimate models with region-level fixed effects (Table A14) to demonstrate that our results are not driven by specific survey areas. 
Another potential concern is that our study faces a "cluster randomization" problem (McCauley and Posner 2015) in the sense that Ivorians in central and western Côte d'Ivoire were not exposed individually to rebel or government controlled-zones, but rather they were exposed as a cluster along with their neighbors. If people who live near each other react in similar ways to the rebel occupation, but differently from people who live farther away, then potential outcomes will be correlated across clusters and the effective sample size of our study is reduced. To address this concern we re-estimate our main regression models using enumeration area-level averages. Table A15 shows that even using this more conservative approach (which reduces the sample size to 50), we find very similar estimates.

Given the time lag between the end of the conflict and the implementation of the survey (2011 to 2018), it is possible that intervening variation in the quality of post-war governance or state-provided patronage among the treated and control groups account for our results. However, in our research context, this type of bias is likely to cut against the direction of our findings. Given that the Ivorian conflict resulted in a victory for the FN-supported candidate, former rebel territories tended to be the primary beneficiaries of development resources and state patronage channeled by the Ouattara government (Piccolino 2018, 493497). Analyses of data from the 2014 ENV survey confirms that households in the former Cenre-Nord-Ouest (CNO) zone reported greater access to loans, financial support, and aid from both government and international agencies. ${ }^{10}$ Thus, it is unlikely that our findings are driven solely by lower-quality post-conflict governance in former rebel areas.

Finally, we consider whether our results can be explained in terms of differential exposure to violence or exposure to third-party (e.g. non-rebel) governance actors. We find that exposure to FN rule does significantly increase the risk of victimization - in governmentcontrolled areas, $35 \%$ of respondents reported that they were victims of physical violence

10 "Enquête Niveau de Vie des Ménages (ENV 2014)," National Institute of Statistics, Republic of Côte d'Ivoire. 
or property theft during the conflict; among respondents in rebel-ruled communities, the rate is $55 \%(p<0.001)$. However, when we repeat the main analysis among victim and nonvictim subsets of respondents (see Appendix Figure A3), we find broadly similar effect estimates among both groups. Moreover, when we add controls for whether respondents reported experiencing visits by UN peacekeeping forces in their community, or received assistance from a national or international NGO during the war, the estimated effects of rebel rule remain unchanged (Table A16). Overall, these tests suggest that something about the experience of rebel rule itself is behind citizens' changed political attitudes.

\section{Exploring Causal Mechanisms}

The analyses above suggest that rebel rule in Côte d'Ivoire had primarily negative effects for democratic citizenship. To explain this finding, we draw on both survey and qualitative evidence, including interviews conducted during two research trips in 2017 and 2018. Interviewees included a range of Ivorian community members including village leaders, civil society activists, public servants, elected officials, and ordinary residents in over thirty former rebel-ruled localities. ${ }^{11}$ We conducted this research prior to the implementation of the survey, but revisited our interview notes to help make sense of the survey findings.

One seemingly obvious explanation is that our findings capture a partisan galvanization effect, wherein exposure to "northern" rebel rule intensified mistrust in the state and skepticism about formal civic duties among Ivorians already inclined to view the post-war Ouattara administration unfavorably. Specifically, in the context of Côte d'Ivoire's ethnically divided society (Akindès 2004), we might expect that coethnics of FN rebels and the Ouattara government would respond differently to exposure to FN rule compared to non-coethnics, with

\footnotetext{
${ }^{11}$ These included localities near the ceasefire line, such as Vavoua and Man, as well as areas further north in former FN territory, such as Korhogo and Bouna.
} 
increased antipathy to the postwar state concentrated among non-coethnics. We evaluate this idea by repeating our analyses among subsets of respondents who self-identified as belonging to Krou, Akan, and Mande ethnic groups. The Krou are generally seen as aligned with Gbagbo's Front populaire ivoirien (FPI) party, while the Mande, and to a lesser extent the Akan, were seen as more supportive of the FN and President Ouattara. If FN rule were galvanizing anti-civic attitudes among those already inclined to distrust the post-conflict Ouattara regime, we would expect to see different outcomes across these sub-groups. Figure 3 shows that there are no such differences: across each set of outcomes, we see generally similar estimates among all three ethnic subsets.

We point to three more general mechanisms. Two of these mechanisms - disrupted norms of compliance and rival governance - are derived from claims in the existing literature. We also propose a third mechanism of unmet expectations, based on the authors' inductive observations. While we cannot provide definitive tests of these mechanisms, we offer suggestive evidence for each on the basis of both qualitative and quantitative findings.

First, the experience of rebel rule and its attendant rupture in state sovereignty appears to have weakened local norms of compliance with "state-like" institutions. In interviews with redeployed state officials in former rebel areas, officials repeatedly complained that local populations were not subjected to the authority of the state for many years, and that this affected their ability to work with the community after reunification. One officer in the gendarmerie, who was redeployed in 2011 to the region of Gbêkê, recalled that when he came back to the region people were "unfamiliar" with the gendarmerie, ignored its authority, and were reluctant to follow official laws (Author interview, 17 July 2017). A sous-préfet in the same region drew a similar picture and insisted that the FN occupation was responsible for what he viewed as a lack of respect for the rule of law, including recent violent protests against the cost of electricity that degenerated into the pillage of a bank and the renovated sous-préfecture building (Author interview, 19 July 2017). Interviews with 

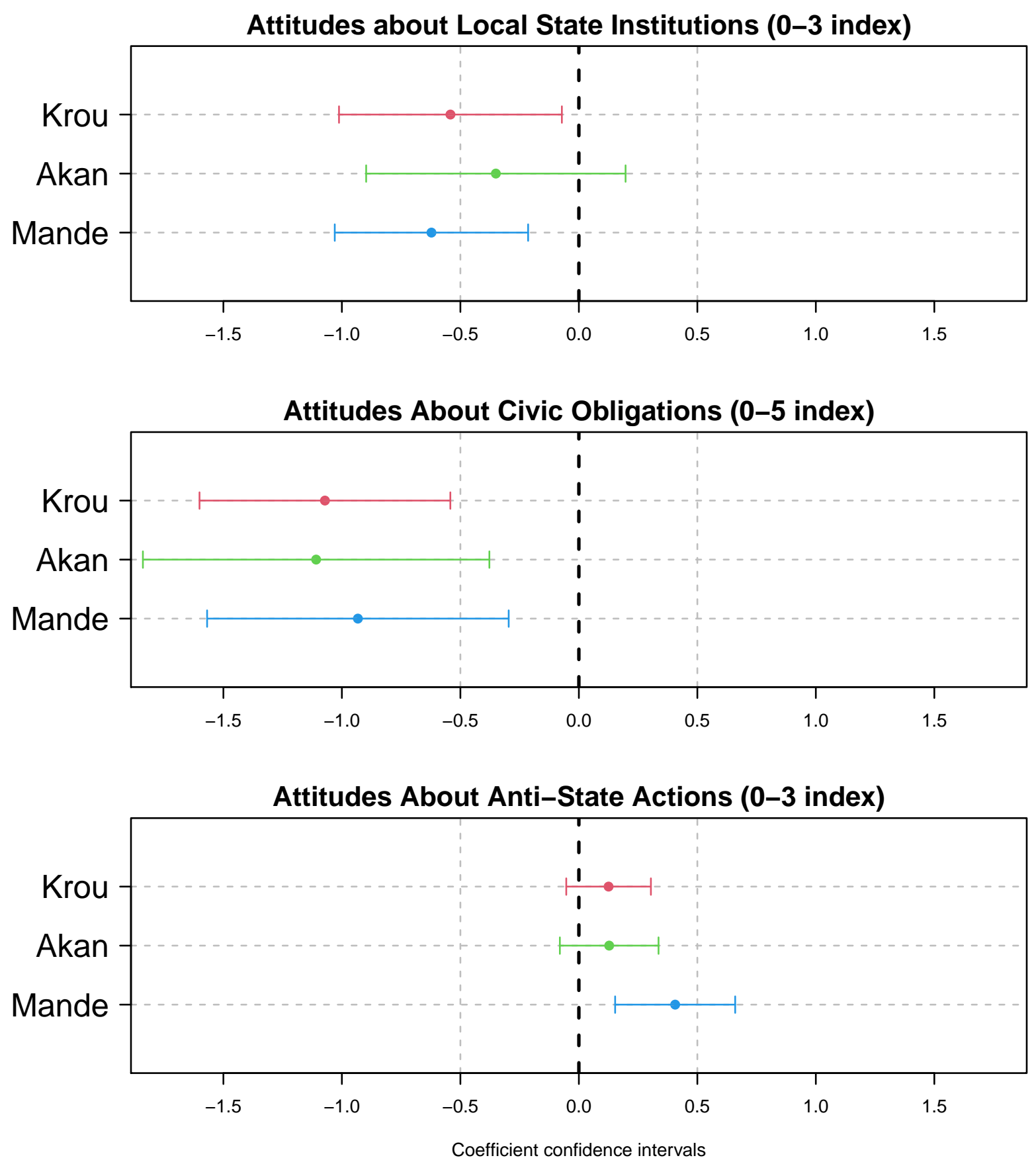

Figure 3: Heterogenous Effects by Ethnicity 
local residents and civil society activists echoed similar themes. Many expressed the view that their communities had been "abandoned" by state authorities during the crisis, which created a lasting reticence to place trust in formal institutions again.

Do the findings from our survey offer quantitative support for this mechanism? To probe this, we repeat our analyses among subsets of respondents who lived in areas where the FN established permanent military camps, versus respondents in areas where rebels only visited periodically. As Förster (2015) documents, areas with permanent FN camps tended to experience more continuity in terms of the presence of "state-like" authority - where local FN commanders often adopted the titles, protocols, and even uniforms of Ivorian state officials - compared to areas without permanent camps, where rebel rule was more informal and sporadic. Thus, comparing areas with and without permanent rebel camps allows us to indirectly assess the disrupted norms of compliance mechanism. Figure 4 shows that while the effects of rebel rule on favorable attitudes towards local state institutions and anti-state actions are not appreciably different across these areas, areas without permanent camps did see greater decreases in attitudes about civic obligations (a two sample t-test confirms the difference in estimates is significant at the $p<0.05$ level).

The rival governance mechanism was also supported by our interviews. In particular, rebel rule in Côte d'Ivoire often triggered community-level collective action, leading some Ivorians to view the post-conflict state as a largely irrelevant governance actor in their own lives. We heard numerous stories of ordinary citizens stepping up to fill service gaps created by the withdrawal of the state. During interviews in the city of Man, for example, interviewees described how university students, retired teachers and other educated individuals joined the ranks of volunteer teaching associations that allowed schools to re-open in many rebel-ruled towns. A member of the volunteer education association Ecole pour Tous in Bouaké similarly recalled: "the initiative was really a community initiative involving every neighbourhood..." (Author interview, Bouaké, July 2017). In the FN-occupied town of 

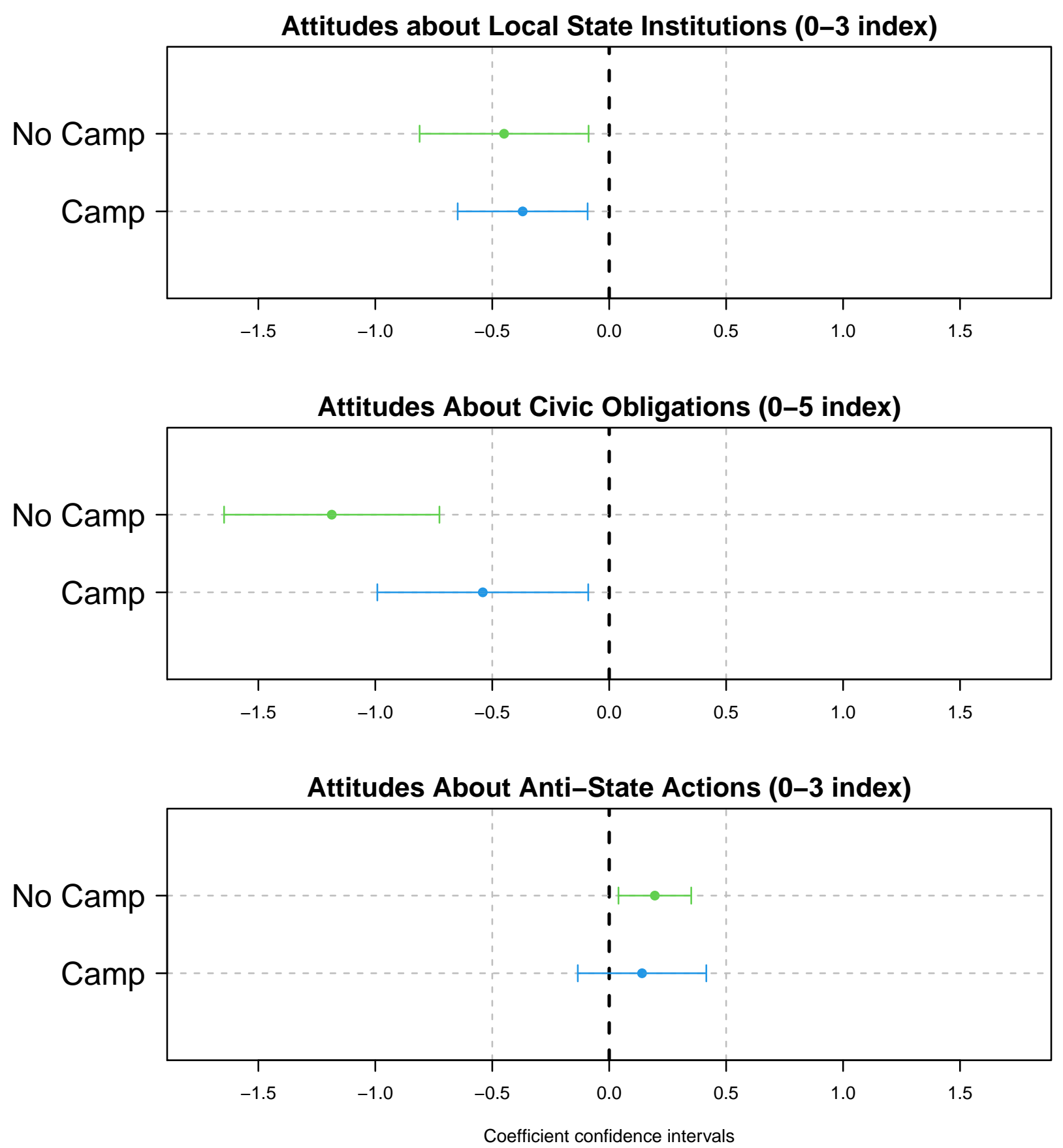

Figure 4: Heterogenous Effects by Presence of Permanent Rebel Camp 
Ouangolodougo (popularly referred to as "Ouangolo"), traders organized the Confédération des Fédérations des Filières Bétail Viandes des Pays Membres de l'Union Economique et Monétaire Ouest Africaine (COFENABVI-PAM-UEMOA) to facilitate the exporting of cattle amid the administrative division of the country (Speight 2015, 193-195). In other cases, civilians self-organized in order to mediate with FN rebels because existing local authorities had fled. In the town of Sakassou, for example, one member of a local women's association explained that she felt obliged to take on new roles during the war, including negotiating with the local FN commander to resolve disputes and obtain essential resources for the community (Author interview, 23 July 2017, Sakassou). And in rare cases, local collective action was spurred by direct confrontations between Ivorian civilians and FN rebels. In the former rebel capital of Bouaké, residents organized public opposition to rebel taxation (Konan 2007). Further north in Bounkani, tense relations between the ethnic Lobi community and FN rebels led local civilians to organize armed self-defense groups (Speight 2015, 114-115).

Many of these community-level governance mechanisms persisted after national re-unification in 2011, and provided a ready alternative to the redeployed state for addressing local issues. The grassroots education initiative Ecole pour Tous, for example, continued to be active in northern Côte d'Ivoire, organizing efforts to improve education access (Popineau 2017). Traders associated with COFENABVI-PAM-UEMOA resisted efforts of the municipal government in Ouangolo to reassert control over local taxation, and attempted to retain their wartime fiscal authority (Speight 2015, 200-203). In the security domain, although the state police and gendarmerie forces were redeployed across the north, many local dozo groups retained their informal policing roles in rebel-ruled territory, particularly concerning issues of cattle theft (Heitz-Tokpa 2019, 156).

To probe the rival governance mechanism quantitatively, we analyze behavioral indices of respondents' participation in both wartime and post-conflict local collective action. To construct the indices, we asked whether, during the rebel occupation and within the last 
six months, respondents had done the following actions: volunteered in a project to help their community, participated in a meeting to discuss problems in the community, joined a civil society organization, served in the governance system of their village or neighbourhood, joined a local party branch, or attended a meeting or demonstration organized by a local party branch. We find that exposure to rebel rule is associated with increases in both wartime and current local collective action behaviors $(p<0.05)$. Moreover, the index of wartime collective action is positively correlated with both recent collective action and negatively correlated with attitudes about civic obligations (full results in Table A17). While not definitive, these results are consistent with the notion that rebel-ruled civilians developed habits of self-help and community solidarity that both outlasted the war and alienated citizens from a broader sense of civic duty towards formal political institutions.

As another piece of suggestive evidence for both the disrupted norms and rival governance mechanisms, we momentarily leave behind our near-border identification strategy and zoom out to all FN-ruled localities covered by our survey (900 respondents across 90 enumeration areas). We ask: conditional on FN control of a locality, does the quality of governance under rebel rule covary with postwar citizen-state relations? Full results are reported in Table A18, which show OLS models that regress our main attitudinal outcome measures on a large number of department, locality, and individual covariates. We find that, within the larger FN zone, respondents who judged that the availability and quality of basic services (specifically policing, health, and education) under FN rule were either "good" or "very good", postwar attitudes about state institutions and civic obligations were also significantly more positive $(p<0.001)$ (though we see no relation between the quality of wartime services and postwar attitudes about anti-state actions). While we cannot interpret these patterns causally given that wartime governance may reflect unobserved traits of these communities (though we control for ethnicity, prewar education, poverty, and social capital), the pattern is nonetheless consistent with both mechanisms noted above: where rebel rule involved a 
more significant deterioration in the quality and reliability of state-like governance, local populations experienced a greater downward shift in the perceived efficacy of formal state institutions, and attendant obligations towards the broader civic community.

A final mechanism that emerged from our interviews revolves around a dynamic of unmet expectations. By this logic, citizen attitudes towards the postwar Ivorian state in rebelruled areas are shaped by resentments caused by the discrepancy between high expectations of a postwar "payoff" and the reality of slow postwar recovery and reconstruction. In many interviews, residents expressed the view that their postwar fates stood in marked contrast with the fortunes of the rebel leaders who once dominated their towns and cities. In the Worodougou area, for example, a poor region of the country where the population strongly supported the political goals of the rebellion and many people joined the FN, a sense of abandonment and deception was prevalent in 2017. Former combatants, residents, and officials alike complained that the leaders of the rebellion exploited the mineral wealth of the area during the division of the country, and then neglected it after taking power in Abidjan (see also Van Bockstael 2019, 911; Grajales 2020). Examining respondent perceptions about local economic conditions in the near-border sample, only $31 \%$ of respondents reported that they felt that local economic conditions had improved in their community since 2011 - a notably low rate, given the country's widely touted post-conflict economic recovery - and only $35 \%$ felt that government rehabilitation projects had benefited their locality. While these views are similar in former rebel and government-controlled areas $(p>0.1)$, perceptions of economic stagnation may have translated into greater frustration in the former rebel zone due to a sense of entitlement to a reward for having sustained the burden of the occupation. 


\section{Discussion}

This study leverages a unique natural experiment in Côte d'Ivoire to examine the long-run impacts of exposure to rebel rule on civilians' political attitudes and sense of democratic citizenship. Comparing communities that fell "just inside" the rebel-occupied zone to those that fell "just outside," we find that citizens exposed to prolonged rule by insurgents became more negative in their views about local government authorities, had a weaker sense of duty to participate in formal civic processes, and became more likely to condone certain (illegal) anti-state actions. These effects are substantively large, are detectable up to seven years after postwar territorial reunification, and occur across both rebel coethnics and non-coethnics and among victims and non-victims of violence.

To explain why exposure to rebel rule negatively impacted these aspects of citizen-state relations in Côte d'Ivoire, we propose a number of mechanisms triggered by rebel rule that weaken the perceived efficacy and legitimacy of formal state institutions relative to local self-help alternatives. First, residents in communities cut off from the state for a protracted period of time may stop seeing such formal government authorities as "natural" and lose the habit of complying spontaneously with civic duties and obligations. Second, rebel rule drove civilians to create new self-governance structures to address service gaps. This local mobilization instilled lasting practices of collective action and shared governance, which ironically may have reinforced the tendency to view redeployed state authorities as unhelpful

or even redundant in the post-conflict period. Finally, disaffection with the state may have been reinforced by unmet expectations of post-conflict recovery. Ultimately, our findings suggest that exposure to rebel rule can lead a broad range of citizens to lose faith in the ability of the government to hold up its end of the state-citizen social contract.

Several features of our study may limit the generalizability of our findings. First, as 
noted above, it is possible that the effects of rebel rule will vary depending on group-level characteristics that our research design cannot fully account for (for example, the ideology of rebel organizations). We therefore expect our findings to generalize best to other cases of "status quo" rebel governance (Mampilly and Stewart 2021). Second, the front lines of the Ivorian civil war remained quite static for a considerable period of time (nine years), and few communities "changed hands" between rebel and government forces. Civil wars with greater turnover in rebel territorial control may generate more civilian victimization (Kalyvas 2006), which could alter levels of post-conflict civic engagement (Blattman 2009). Exposure to rebel rule for shorter time periods may also result in weaker effects than those we observe. Third, the Ivorian civil war was characterized by segmented and well-defined spheres of rebel and government influence. In conflicts where government authorities maintain a significant foothold in zones of rebel presence, citizens may retain stronger habits of compliance with state institutions. Overall, we expect our findings to generalize best to other situations of rebel rule in countries with a history of indirect rule and weak penetration of the central state in society, where determined challenger groups manage to seize territory and cut off civilian populations from government administration over a prolonged period. This description fits a significant number of ongoing conflicts, including the Central African Republic, Libya, Chad, Sudan, and Mali.

More broadly, our findings contribute to ongoing debates about the political legacies of civil war. We show that the impacts of exposure to rebel rule for citizen attitudes towards formal democratic institutions can be widespread and lasting, mainly in negative ways. These results resonate with scholarship emphasizing the destructive effects of conflict for development (Collier et al. 2003). While a recent wave of research on victimization suggests that conflict may sometimes build trust and political participation (Bauer et al. 2016), our evidence underscores that other wartime processes point in the opposite direction. Our study therefore underscores the need to look beyond violence to fully understand the nuanced 
political legacies of armed conflict. Nonviolent processes that operate at the community-level - including dynamics of rebel rule - may be equally or even more important than violence for trajectories of statebuilding and peacebuilding. Overall, our findings are consistent with recent research that underscores how wartime governance and order-creating institutions influence the direction of state formation after civil war (Péclard et al. 2019), including by shaping beliefs, norms, and political relations at the individual and community level (Arjona 2016, 310-311). Future research might usefully investigate the attitudinal and behavioral legacies of varied types of rebel political control (for example comparing revolutionary and non-revolutionary insurgents), as well as rule by other non-state groups such as criminal gangs or pro-government paramilitaries.

For policymakers, our study underscores that peacebuilders confront a challenging task in zones formerly controlled by non-state armed groups, even after these groups are dismantled or integrated into the state. Efforts to revive strong civic identities and trust in state institutions are likely to take considerable time. Nevertheless, there is some cause for a more positive outlook. First, local solidarity and collective action are clearly sources of resiliency for rebel-ruled communities, which may help to offset state capacity shortfalls during postconflict reconstruction. Second, it is possible that increased citizen skepticism of the state may ultimately contribute to democratic accountability in the long run, by forcing redeployed government agents to be more attentive to the demands of citizens in order to garner their support. We leave it to future research to assess such claims.

\section{Acknowledgements}

We would like to thank the United States Agency for International Development Côte d'Ivoire, particularly Benjamin Olagboye and Krista Desgranges Elkhamri, for generously supporting the survey on which this article is based. The project also benefited from a fellow- 
ship awarded to Jeremy Speight by the British Academy. We also thank Kaphalo Segorbah Silwe and Joseph Koné of the Centre de Recherche et de Formation sur le Développement Intégré (CREFDI), along with the survey enumeration team members. We received helpful comments from Reyko Huang, Romain Malejacq, Nina McMurry, Lee J.M. Seymour, Leigh Spanner, Juan Tellez, and participants at the Canadian Political Science Association 2019 meeting, the American Political Science Association 2019 meeting, the workshop on Côte d'Ivoire organized by the University of Paris 1 Pantheon-Sorbonne in 2019, the International Studies Association 2021 meeting, and the 2021 workshop Perspectives on Governance by Non-State Armed Actors organized by Scuola Sant'Anna. 


\section{References}

Akindès, Francis. 2004. The roots of the military-political crises in Côte D'Ivoire. Uppsala: The Nordic Africa Institute.

Albert, Karen Elizabeth. 2020. Institutions of the Weak: Rebel Institutions and the Prospects of Peace After Civil War. PhD thesis University of Rochester.

Allouche, Jeremy and Hyacinthe Digbeugby Bley. 2017. "Une histoire politique du Tonkpi dans l'Ouest ivoirien." Afrique contemporaine 3(263):157-176.

Arjona, Ana. 2014. "Wartime institutions: A research agenda." Journal of Conflict Resolution 58(8):1360-1389.

Arjona, Ana. 2016. Rebelocracy. New York: Cambridge University Press.

Arjona, Ana, Nelson Kasfir and Zachariah Mampilly. 2015. Rebel governance in civil war. New York: Cambridge University Press.

Bakke, Kristin M, Andrew M Linke, John O'Loughlin and Gerard Toal. 2018. "Dynamics of state-building after war: External-internal relations in Eurasian de facto states." Political Geography 63:159-173.

Bakke, Kristin M, John O'Loughlin, Gerard Toal and Michael D Ward. 2014. "Convincing state-builders? Disaggregating internal legitimacy in Abkhazia." International Studies Quarterly 58(3):591-607.

Balcells, Laia. 2017. Rivalry and revenge. New York: Cambridge University Press.

Barter, Shane. 2016. Civilian strategy in civil war: Insights from Indonesia, Thailand, and the Philippines. New York: Palgrave Macmillan. 
Bassett, Thomas. 2011. "The costs of the road in a divided Côte d'Ivoire." Cultural Anthropology .

URL: https://culanth. org/fieldsights/190-the-costs-of-the-road-in-a-divided-cote-d-ivoire

Bauer, Michal, Christopher Blattman, Julie Chytilová, Joseph Henrich, Edward Miguel and Tamar Mitts. 2016. "Can war foster cooperation?" Journal of Economic Perspectives $30(3): 249-74$.

Blattman, Christopher. 2009. "From violence to voting: War and political participation in Uganda." American Political Science review 103(2):231-247.

Boone, Catherine. 2014. Property and political order in Africa: Land rights and the structure of politics. New York: Cambridge University Press.

Cassar, Alessandra, Pauline Grosjean and Sam Whitt. 2013. "Legacies of violence: Trust and market development." Journal of Economic Growth 18(3):285-318.

Charbonneau, Bruno. 2012. "War and peace in Côte d'Ivoire: Violence, agency, and the local/international line." International Peacekeeping 19(4):508-524.

Chauveau, Jean-Pierre. 2000. "Question foncière et construction nationale en Côte d'Ivoire." Politique africaine (2):94-125.

Chelpi-den Hamer, Magali. 2011. Militarized youths in Western Côte d'Ivoire: Local processes of mobilization, demobilization, and related humanitarian interventions (20022007). African Studies Center: African Studies Collection.

Collier, Paul et al. 2003. Breaking the conflict trap: Civil war and development policy. World Bank Publications.

Cunningham, David E, Kristian Skrede Gleditsch and Idean Salehyan. 2013. "Non-state actors in civil wars: A new dataset." Conflict Management and Peace Science 30(5):516531. 
De Juan, Alexander and Jan Henryk Pierskalla. 2016. "Civil war violence and political trust: Microlevel evidence from Nepal." Conflict Management and Peace Science 33(1):67-88.

De Luca, Giacomo and Marijke Verpoorten. 2015. "Civil war, social capital and resilience in Uganda." Oxford Economic Papers 67(3):661-686.

Dreier, Sarah K and Milli Lake. 2019. "Institutional legitimacy in sub-Saharan Africa." Democratization 26(7):1194-1215.

Dunning, Thad. 2008. "Improving causal inference: Strengths and limitations of natural experiments." Political Research Quarterly 61(2):282-293.

Fofana, Moussa. 2011. "Des Forces nouvelles aux Forces républicaines de Côte d'Ivoire." Politique africaine (2):161-178.

Fofana, Moussa. 2012. "Ethnographie des trajectoires sociales des jeunes enrôlés dans la rébellion en Côte d'Ivoire." PhD thesis Université Alassane Ouattara, Bouaké.

Förster, Till. 2015. Dialogue direct: Rebel governance and civil order in northern Côte d'Ivoire. In Rebel Governance in Civil War, ed. Nelson Kasfir Ana Arjona and Zachariah Mampilly. New York: Cambridge University Press pp. 203-225.

Freitag, Markus, Sara Kijewski and Malvin Oppold. 2017. "War experiences, economic grievances, and political participation in postwar societies: An empirical analysis of Kosovo." Conflict management and peace science 36(4):405-424.

Global IDP Project, IDP. 2005. "Internal displacement in Côte d'Ivoire: a protection crisis.". URL: https://www.internal-displacement.org/publications/internal-displacement-in-cotedivoire-a-protection-crisis

Grajales, Jacobo. 2020. "Losing land in times of peace: Post-war agrarian capitalism in Colombia and Côte d'Ivoire." The Journal of Peasant Studies 48(5):1-21. 
Hamer, Magali Chelpi-Den. 2007. "How to certify learning in a country split into two by a civil war: Governmental and non-governmental initiatives in Côte d'Ivoire, 2002-06." Research in Comparative and International Education 2(3):191-209.

Heitz, Kathrin. 2009. "Power-sharing in the local arena: Man - a rebel-held town in Western Côte d'Ivoire." Africa Spectrum 44(3):109-131.

Heitz Tokpa, Katharina. 2013. Trust and Distrust in Rebel-Held Côte d'Ivoire. PhD thesis University of Basel.

Heitz-Tokpa, Kathrin. 2019. "Mande hunters and the state: Cooperation and contestation in post-conflict Côte d'Ivoire." African Studies Review 62(1):148-172.

Hoskins, Bryony L and Massimiliano Mascherini. 2009. "Measuring active citizenship through the development of a composite indicator." Social indicators research 90(3):459488.

Huang, Reyko. 2016. The wartime origins of democratization: Civil war, rebel governance, and political regimes. New York: Cambridge University Press.

Internal Displacement Monitoring Centre, IDMC. 2012. "Côte d'Ivoire: IDPs rebuilding lives amid a delicate peace.".

URL: https://www.internal-displacement.org/publications/cote-divoire-idps-rebuildinglives-amid-a-delicate-peace

International Crisis Group, ICG. 2003. "Côte d'Ivoire: The war is not yet over.".

URL: $\quad$ https://d2071andvip0wj.cloudfront.net/72-cote-d-ivoire-the-war-is-not-yetover $_{0} \cdot p d f$

Kalyvas, Stathis N. 2006. The logic of violence in civil war. New York: Cambridge University Press. 
Karim, Sabrina. 2020. "Relational state building in areas of limited statehood: Experimental evidence on the attitudes of the police." American Political Science Review 114(2):536551.

Kasfir, Nelson. 2005. "Guerrillas and civilian participation: the National Resistance Army in Uganda, 1981-86." Journal of Modern African Studies pp. 271-296.

Konan, Marcel. 2007. "Deux manifestations blessés a Bouaké." Nord-Sud (9 November).

Kubota, Yuichi. 2017. "Imagined statehood: Wartime rebel governance and post-war subnational identity in Sri Lanka." World Development 90:199-212.

Kubota, Yuichi. 2018. "Nonviolent interference in civic life during civil war: Rebel service provision and postwar norms of interpersonal trustworthiness in Sri Lanka." Security Studies 27(3):511-530.

Mampilly, Zachariah Cherian. 2011. Rebel rulers: Insurgent governance and civilian life during war. Ithaca and London: Cornell University Press.

Mampilly, Zachariah and Megan A Stewart. 2021. "A typology of rebel political institutional arrangements." Journal of Conflict Resolution 65(1):15-45.

Martin, Philip A. 2021. "Commander-community ties after civil war." Journal of Peace Research 58(4):778-798.

Martin, Philip A., Giulia Piccolino and Jeremy S. Speight. 2021a. "Ex-Rebel Authority after Civil War: Theory and Evidence from Côte d'Ivoire." Comparative Politics 53(2):209-232.

Martin, Philip, Giulia Piccolino and Jeremy Speight. 2021b. "Replication data for: The political legacies of rebel rule: Evidence from a natural experiment in Côte d'Ivoire.". URL: doi:10.7910/DVN/IHDBTY

Martone, Gerald. 2003. "The crisis in West Africa: A region suffers from war, poverty, and disease." The American Journal of Nursing 103(9):32-40. 
McCauley, John F and Daniel N Posner. 2015. "African borders as sources of natural experiments: Promise and pitfalls." Political Science Research and Methods 3(2):409-418.

Paffenholz, Thania and Christoph Spurk. 2006. "Civil society, civic engagement, and peacebuilding.". The World Bank: Social Development Papers, Conflict Prevention and Reconstruction, No. 36 .

Paris, Roland and Timothy D Sisk. 2009. The dilemmas of statebuilding: Confronting the contradictions of postwar peace operations. London: Routledge.

Péclard, Didier and Delphine Mechoulan. 2015. Rebel governance and the politics of Civil War. Vol. 1 Bern: swisspeace - Schweizerische Friedensstiftung.

Péclard, Didier, Martina Santschi, Jon Schubert, Gilson Lazaro, Leben Moro and Ousmane Zina. 2019. Civil wars and state formation: Violence and the politics of legitimacy in Angola, Côte d'Ivoire and South Sudan. Working paper University of Geneva/Swiss Network of International Studies (SNIS).

Piccolino, Giulia. 2018. "Peacebuilding and statebuilding in post-2011 Côte d'Ivoire: A victor's peace?" African Affairs 117(468):485-508.

Popineau, Camille. 2017. "Prendre la craie. La mobilisation des enseignants rebelles dans le Nord de la Côte d'Ivoire (2002-2011)." Politique africaine (4):27-48.

Reno, William. 1999. Warlord politics and African states. Boulder, CO: Lynne Rienner Publishers.

Schmelzle, Cord and Eric Stollenwerk. 2018. "Virtuous or vicious circle? Governance effectiveness and legitimacy in areas of limited statehood." Journal of Intervention and Statebuilding 12(4):449-467.

Sciolino, Elaine. 2002. "Ivory Coast's raging conflict draws France in." The New York Times p. 3 . 
Smith, Stephen. 2002. "Le bain de sang évité, la trêve ouvre la voie à une périlleuse négociation." Le Monde .

Speight, Jeremy. 2015. Big-Men coalitions and political order in northern Côte d'Ivoire (2002-2013). PhD thesis Concordia University.

Stewart, Megan A. 2018. "Civil war as state-making: Strategic governance in civil war." International Organization 72(1):205-226.

van Baalen, Sebastian. 2021. "Local elites, civil resistance, and the responsiveness of rebel governance in Côte d'Ivoire." Journal of Peace Research pp. 1-15.

URL: https://doi.org/10.1177/0022343320965675

Van Bockstael, Steven. 2019. "Land grabbing "from below"? Illicit artisanal gold mining and access to land in post-conflict Côte d'Ivoire." Land use policy 81:904-914.

Verba, Sidney and N.H. Nie. 1987. Participation in America: Political democracy and social equality. Chicago: University of Chicago Press.

Voors, Maarten J, Eleonora EM Nillesen, Philip Verwimp, Erwin H Bulte, Robert Lensink and Daan P Van Soest. 2012. "Violent conflict and behavior: A field experiment in Burundi." American Economic Review 102(2):941-64.

Weinstein, Jeremy M. 2006. Inside rebellion: The politics of insurgent violence. New York: Cambridge University Press.

Wood, Elisabeth Jean. 2003. Insurgent collective action and civil war in El Salvador. New York: Cambridge University Press.

Wood, Elisabeth Jean. 2008. "The social processes of civil war: The wartime transformation of social networks." Annual Review of Political Science 11:539-561. 
Wood, Elisabeth Jean. 2015. Social mobilization and violence in civil war and their social legacies. In The Oxford handbook of social movements. Oxford University Press pp. 452467. 


\section{Online Appendix}

"The Political Legacies of Rebel Rule: Evidence from a Natural Experiment in Côte d'Ivoire" 


\section{Appendix A: Spatial-Temporal Development of the Rebel Frontline in Ivory Coast}

The timeline below was compiled on the basis of the following sources: Chelpi-den Hamer 2011; Heitz Tokpa 2013; Human Rights Watch (2003); and Le Monde articles.

- September 19, 2002: Mutineers launch coup attempt in Abidjan

- September 21, 2002: Newspapers report that Bouaké and Korhogo are in the hands of the insurgents. Sporadic fighting among governmental troops travelling towards Bouaké and the insurgents is reported (Le Monde, 21 September 2002; Le Monde, 24 September 2002).

- September 26, 2002: Insurgents occupy the city of Odienné in the north west without encountering any major resistance. They also occupy Ferkéssédougou, $50 \mathrm{~km}$ east of Korhogo (Le Monde, 30 September 2002; Le Monde, 1 October 2002).

- September 28, 2002: Reports from refugees that the rebels have extended their presence to the border areas with Burkina Faso, de facto controlling all the north of the country (Le Monde, 1 October 2002). According to rebel sources, a French helicopter opened fire on the insurgents in Tiébissou, $66 \mathrm{~km}$ south of Bouaké, the city that now marks the boundary between government and rebel controlled areas (Le Monde, 2 October 2002).

- September 29, 2002: Rebel forces advance west and south, taking Sakassou, $43 \mathrm{~km}$ from Bouaké, without encountering significant resistance. The rebels also start calling themselves Mouvement patriotique de Côte d'Ivoire (MPCI) and talk about their political program (Le Monde, 3 October 2002).

- October 3 - October 6, 2002: Attempts by ECOWAS to negotiate a ceasefire fail. 
- October 7, 2002: Fighting resumes. The Ivorian army stages a surprise attack on Bouaké and Sakassou. It manages to occupy Sakassou, but it is pushed back by the MPCI from Bouaké after a day of fighting (Le Monde, 8 October 2002; Le Monde, 9 October 2002). First reports of MPCI-aligned rebel attacks in western districts of Montagnes and Sassandra-Marahoue. Vavoua is captured by rebel forces (Chelpi-den Hamer 2011).

- October 11, 2002: Rebel forces moving south from Vavoua reach Daloa and capture the city (Chelpi-den Hamer 2011).

- October 14-15, 2002: Loyalist forces retake Daloa (Human Rights Watch, 2003).

- October 17, 2002: A ceasefire brokered by Senegal temporarily halts further fighting (Le Monde, 19 October 2002).

- November 3-4, 2002: Rebel forces attack the local firm Sucrivoire in Borotou-Koro, $150 \mathrm{~km}$ north of Man (Chelpi-den Hamer 2011).

- November 28, 2002: MPCI-aligned rebel forces take the towns of Man, Danané and Zouan-Hounien on 28 November (Liberation, 29 November 2002). Man is recaptured 2 days later by loyalist forces (Human Rights Watch, 2003).

- December 2, 2002: Rebel forces capture Toulepleu (Human Rights Watch 2003).

- December 6, 2002: Rebel forces capture Blolequin (Human Rights Watch 2003).

- December 19-20, 2002: Rebel forces recapture Man, Bangolo and surrounding villages (Human Rights Watch 2003).

- January 10-12, 2003: Loyalist forces recapture Toulepleu (Chelpi-den Hamer 2011).

- April 6-14, 2003: Fighting between rebel and government forces in Zouan-Hounien, which is recaptured by loyalist forces (Chelpi-den Hamer 2011). 
- May 23, 2003: Zone de Confiance is formally established under French and UN auspices, giving official recognition to the de facto ceasefire line on the ground (Chelpi-den Hamer 2011).

Discussion. The timeline of events suggests that by the time MPCI/FN rebels were expanding from the north into the western regions of our study, they were expanding territorial control at a rate of between 15 and $24 \mathrm{~km}$ per day, or about $20 \mathrm{~km}$ on average. The MPCI/FN's "western push" began within one week of the rebellion onset. The rebel capture of Odienné on September 26, a town $235 \mathrm{~km}$ west of Korgogo, suggests an initial rate of territorial expansion of approximately $47 \mathrm{~km}$ per day. The subsequent capture of Vavoua on October 7, $267 \mathrm{~km}$ further south from Boundiali, implies a rate of expansion of approximately $22 \mathrm{~km}$ per day between September 26 and October 7. The subsequent capture of Daloa on October 11, only four days after the capture of Vavoua, suggests a rate of rebel expansion of about $15 \mathrm{~km}$ per day by mid-October. After the resumption of rebel offensives in November (after the mid-October ceasefire), rebels expanded from Danané (captured November 28) to Toulepleu (captured December 2) in four days. This suggests a rate of expansion of about $24 \mathrm{~km}$ per day. (There are multiple reasons for the slow-down in the rebel expansion rate. It was partly due to the increased capacities of the Ivorian loyalist forces, boosted by an influx of foreign mercenaries and new weapons (particularly combat helicopters), as well as a bolstered deployment by the French army to cover the entire western region of Côte d'Ivoire. Between September 2002 and May 2003, French troops increased from about 900 to 3800, and gained the support of an additional 1500 ECOWAS troops and established permanent posts in Duékoué in December, where they actively clashed with rebel forces). Thus, even assuming that rebel forces would have continued to conquer territory at the slower end of this range, if French interposition forces had arrived to halt the offensives even one week later, the ceasefire line might have been over $100 \mathrm{~km}$ further south and all of the governmentcontrolled areas in our study would have been under rebel control. If foreign intervention 
had arrived two weeks later, MPCI/FN rebels might have conquered nearly all the way to San Pédro on the Atlantic coast. 


\section{Appendix B: Survey}

The data used in this study is drawn from the Citizen Perceptions Survey project, conducted in August-September 2018. The Citizen Perceptions Survey was funded by USAID Côte d'Ivoire in the context of the Political Transition and Inclusion (PTI) initiative, a component of USAID Côte d'Ivoire's Political Inclusion and Accountability (PIA) project, which aims to improve inclusion and government responsiveness to citizens' interests and grievances. A key purpose of the survey was to gauge citizen attitudes about governance, citizenship, and local political inclusion in formerly conflict-affected areas of the country, which were identified by USAID Côte d'Ivoire as priority areas for the PIA project in the lead-up to the 2020 national elections. The Citizen Perceptions Survey was administered by the authors in partnership with a local survey firm, the Center for Research and Training for Integrated Development (CREFDI). CREFDI is the Afrobarometer partner in Côte d'Ivoire. IRB approval for this study was obtained from the Massachusetts Institute of Technology Committee on the Use of Humans as Experimental Subjects (COUHES), Protocol 1606619582A001.

The base sampling frame for the survey consisted of all sub-prefectures and communes in Côte d'Ivoire that were controlled by the FN rebel group during the 2002-2011 civil war. An additional five regions from the government-controlled zone - all of which were adjacent to the rebel zone - were also included in a supplementary sampling frame, to enable comparative analyses of respondents in former rebel- and government-controlled areas. The total number of respondents reached was 1200 across 120 enumeration sites (Figure A1). In the present study, we focus only on the subset of 50 enumeration sites (500 respondents) located within $100 \mathrm{~km}$ of the ceasefire line. Geographic distances were calculated using Google Maps, which provided data visualization and distance estimates along local roads.

In preparation for implementing the survey in the field, CREFDI recruited 20 Ivorian interviewers with previous experience conducting survey research with them, with an even 


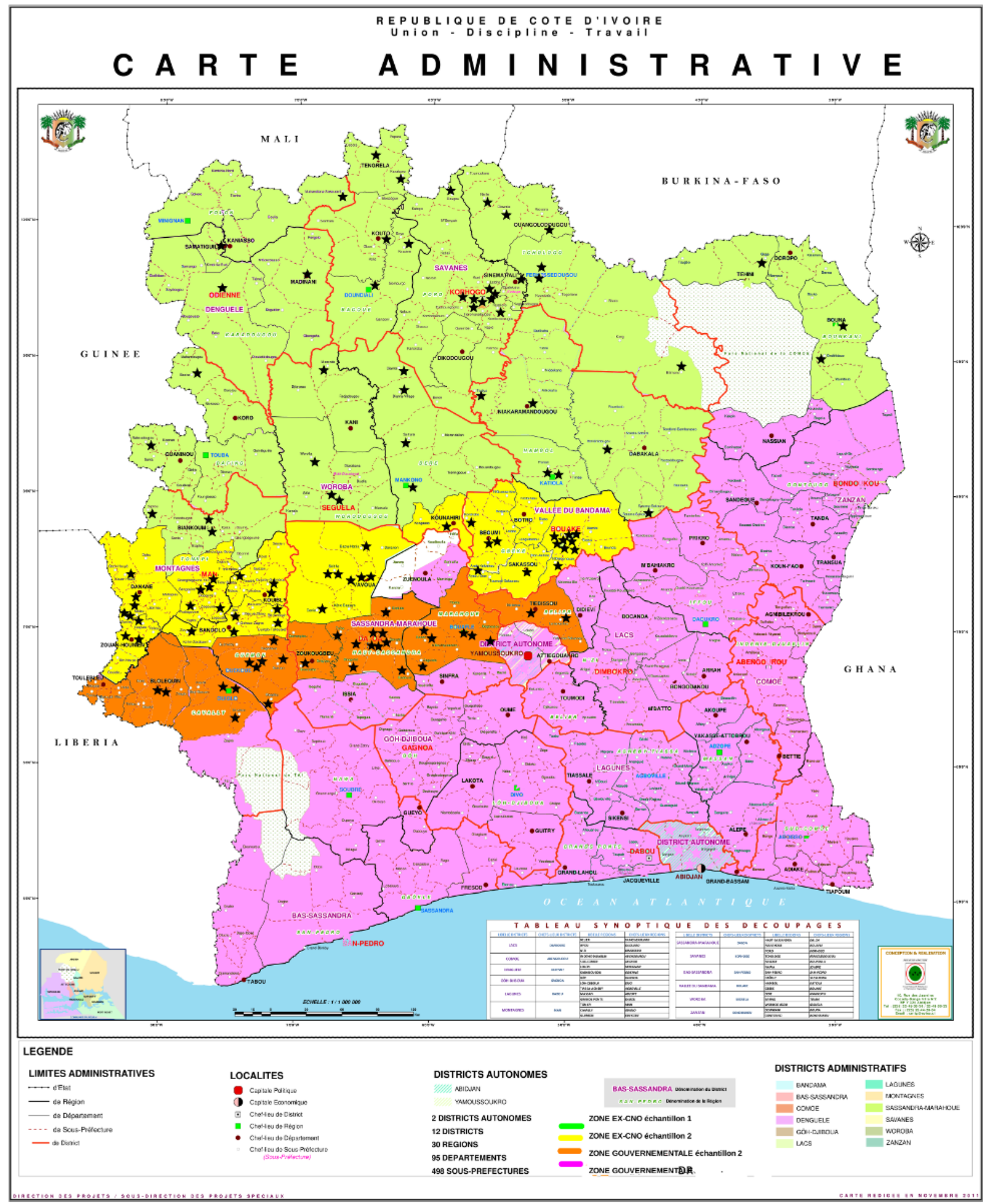

Figure A1: Citizen Perceptions Survey, Enumeration Sites 
gender split. For logistical and security reasons, the interviewers were divided into four field teams with a supervisor and a $4 \times 4$ vehicle each. Along with CREFDI staff, two of the authors helped to faciliate a five day training in August 2018 with the interviewers and team supervisors, and implemented a pilot survey in Bingerville, a suburb of Abidjan.

In line with standard Afrobarometer polling methodology, a random-walk grid method was used to identify households for survey enumeration, with an even split between male and female respondents. Informed consent was obtained from each respondent prior to the survey interview. Surveys were conducted in-person with the assistance of computer tablets. The survey was administered in two languages, French and Dioula, which are the most widely spoken in Côte d'Ivoire. The survey instrument was designed by the authors in collaboration with USAID and incorporated extensive feedback from CREFDI staff as well as local Ivorian researchers. CREFDI staff translated the questionnaire into Dioula and uploaded both versions onto tablets using the software SurveyToGo.

The survey instrument is available here:

https://drive.google.com/file/d/1llODxhsyOYrNcfHFtBaS26SVCGc5sTkN/view?usp=sharing 


\section{Appendix C: Covariates and Descriptive Statistics}

- Treated: Binary variable coded 1 if enumeration area site was in FN-controlled zone, 0 otherwise. To code each enumeration site, we relied on geographic maps of FN territory provided by Ivorian National Institute of Statistics and from the Center for Research and Training for Integrated Development (CREFDI).

- Education: A department-level measure of educational attainment in May 2002, averaged across all households $(0=$ No formal education, $1=$ Primary education, $2=$ Secondary education, $3=$ Post-secondary education). Source: "Enquête Niveau de Vie des Ménages, ENV 2002," National Institute of Statistics, Republic of Côte d'Ivoire.

- Poverty: A department-level measure of poverty rates in May 2002, averaged across all households. Households receive a score of 1 if their per-capita household expenditures fell below the national poverty line in 2002 (183, 450 CFA), and 0 otherwise. Source: "Enquête Niveau de Vie des Ménages, ENV 2002," National Institute of Statistics, Republic of Côte d'Ivoire.

- Age: The age of the respondent in years.

- Christian: Binary variable coded 1 if respondent identified their primary religion as Christianity, 0 otherwise.

- Mande: Binary variable coded 1 if respondent identified their ethnic group as Mande/Malinke, 0 otherwise.

- Akan: Binary variable coded 1 if respondent identified their ethnic group as Akan, 0 otherwise.

- Krou: Binary variable coded 1 if respondent identified their ethnic group as Krou, 0 otherwise.

- Female: A binary variable coded 1 if the respondent identified themselves as female, 0 otherwise.

- Victim: A binary variable coded 1 if the respondent reported they were the victim of physical violence or property theft during the crisis, 0 otherwise.

- Urban: A binary variable coded 1 if the respondent's enumeration area is located in an urban locality, 0 otherwise.

- Years Lived: The number of years the respondent has lived in their current locality (commune or sub-prefecture).

- Education (individual): An ordinal variable indicating the level of education of the respondent $(0=$ No formal education, $1=$ Primary education, $2=$ Secondary education, $3=$ Post-secondary education). 
- Poverty (individual): An ordinal variable indicating the level of poverty reported by the respondent $(0=$ No lived poverty, $1=$ Moderate lived poverty, $2=$ High lived poverty. The definition of lived poverty is based on the Afrobarometer Lived Poverty Index (LPI).)

- Social Assistance (prewar): A department-level measure of local social capital in May 2002, averaged across all households. Households receive a score of 1 if the household head reported receiving financial assistance from a community organization or credit cooperative in the last 12 months, and 0 otherwise. Source: "Enquête Niveau de Vie des Ménages, ENV 2002," National Institute of Statistics, Republic of Côte d'Ivoire.

- Received Loan from Neighbor (prewar): A department-level measure of local social capital in May 2002, averaged across all households. Households receive a score of 1 if the household head reported receiving a loan from a neighbor in the last 12 months, and 0 otherwise. Source: "Enquête Niveau de Vie des Ménages, ENV 2002," National Institute of Statistics, Republic of Côte d'Ivoire.

- Willing to Adopt Child (prewar): A department-level measure of local social capital in May 2002, averaged across all households. Households receive a score of 1 if the household head reported that the household would be willing to take in a non-familial child in crisis, and 0 otherwise. Source: "Enquête Niveau de Vie des Ménages, ENV 2002," National Institute of Statistics, Republic of Côte d'Ivoire.

- Social Capital Index (prewar): An aggregate index of Social Assistance from Neighbor, Received Loan from Neighbor, and Willing to Adopt Child.

- Permanent Camp: A binary indicator for whether respondent indicated that a permanent FN camp existed in their locality during the 2002-2011 crisis.

- Peacekeeping: A binary indicator for whether respondent indicated that impartial UN or French peacekeeping forces visited their locality during the 2002-2011 crisis.

- $N G O$ : A binary indicator for whether respondent indicated that an international nongovernment organization (e.g. MSF) provided services in their locality during the 2002-2011 crisis.

- Paid Taxes to Rebels: A binary indicator for whether respondent indicated that they paid a tax or tribute at least once to an FN rebel during the 2002-2011 crisis.

- Wartime Order: A dummy variable for whether respondent indicated that order and crime-fighting services functioned "well" or "very well" in their locality during the 2002-2011 crisis.

- Wartime Education: A dummy variable for whether respondent indicated that education services functioned "well" or "very well" in their locality during the 2002-2011 crisis.

- Wartime Health: A dummy variable for whether respondent indicated that health services functioned "well" or "very well" in their locality during the 2002-2011 crisis. 
- Wartime Services (index): Aggregate index of Wartime Order, Wartime Education, and Wartime Health.

- RDR 2001 Vote: Share of votes for the RDR in 2001 municipal elections, calculated at sub-prefecture/commune level. Source: Sebastian van Baalen. Guns and Governance: Local Elites and Rebel Governance in Côte d'Ivoire. Diss. Department of Peace and Conflict Research, Uppsala University, 2020.

- ACLED Events (fall 2002) Count of the number of violent events (battles or violent clashes) from September to December 2002, calculated at sub-prefecture level. Source: ACLED.

- Cocoa Farmer: The percentage of households engaged in cocoa farming, averaged at the department level. Source: Source: "Enquête Niveau de Vie des Ménages, ENV 2002," National Institute of Statistics, Republic of Côte d'Ivoire.

- Soil Quality: Average soil quality (nutrient availability), calculated at sub-prefecture level. Source: Harmonized World Soil Database v 1.2.

- Annual Precipitation: Average yearly precipitation in $\mathrm{mm}$, calculated at sub-prefecture level. Source: WorldClim project. 
Table A1: Descriptive Statistics

\begin{tabular}{|c|c|c|c|c|c|c|}
\hline & $\mathrm{N}$ obs & Min & Max & Median & Mean & Std. Dev \\
\hline Treated & 500 & 0 & 1 & 0 & 0.44 & 0.50 \\
\hline Age & 500 & 18 & 87 & 31 & 34.02 & 13.23 \\
\hline Christian & 500 & 0 & 1 & 1 & 0.50 & 0.50 \\
\hline Muslim & 500 & 0 & 1 & 0 & 0.32 & 0.47 \\
\hline Mande & 500 & 0 & 1 & 0 & 0.32 & 0.47 \\
\hline Akan & 500 & 0 & 1 & 0 & 0.21 & 0.41 \\
\hline Krou & 500 & 0 & 1 & 0 & 0.26 & 0.44 \\
\hline Education & 500 & 0.16 & 2.12 & 0.75 & 0.83 & 0.46 \\
\hline Female & 500 & 0 & 1 & 0.50 & 0.50 & 0.50 \\
\hline Poverty & 500 & 0.28 & 0.88 & 0.51 & 0.51 & 0.18 \\
\hline Victim & 500 & 0 & 1 & 0 & 0.44 & 0.50 \\
\hline Urban & 500 & 0 & 1 & 0 & 0.44 & 0.50 \\
\hline Social Assistance (prewar) & 500 & 0 & 0.30 & 0.01 & 0.05 & 0.09 \\
\hline Received Loan from Neighbor (prewar) & 500 & 0.48 & 0.91 & 0.67 & 0.69 & 0.13 \\
\hline Willing to Adopt Child (prewar) & 500 & 0.26 & 0.81 & 0.54 & 0.55 & 0.14 \\
\hline Social Capital Index (prewar) & 500 & 1.14 & 1.67 & 1.29 & 1.31 & 0.15 \\
\hline Permanent Camp & 500 & 0 & 1 & 0 & 0.28 & 0.45 \\
\hline Peacekeeping & 500 & 0 & 1 & 1 & 0.71 & 0.46 \\
\hline NGO & 500 & 0 & 1 & 1 & 0.68 & 0.47 \\
\hline Paid Taxes to Rebels & 500 & 0 & 1 & 0 & 0.35 & 0.48 \\
\hline Wartime Order & 500 & 0 & 1 & 0.50 & 0.50 & 0.50 \\
\hline Wartime Education & 500 & 0 & 1 & 1 & 0.79 & 0.40 \\
\hline Wartime Health & 500 & 0 & 1 & 1 & 0.77 & 0.42 \\
\hline RDR 2001 Vote & 320 & 0 & 52.94 & 32.64 & 28.12 & 17.63 \\
\hline ACLED Events (fall 2002) & 500 & 0 & 5 & 0 & 0.80 & 1.34 \\
\hline Cocoa Farmer & 500 & 0.11 & 0.15 & 0.12 & 0.13 & 0.02 \\
\hline Soil Quality & 500 & 2 & 4.25 & 2.80 & 2.73 & 0.40 \\
\hline Annual Precipitation & 500 & 82.40 & 138.08 & 98.52 & 103.79 & 14.99 \\
\hline State attitudes index & 500 & 0 & 3 & 2 & 1.58 & 1.15 \\
\hline Municipal government & 500 & 0 & 1 & 0 & 0.33 & 0.47 \\
\hline Policy / Gendarmerie & 500 & 0 & 1 & 1 & 0.66 & 0.47 \\
\hline Prefectoral corps & 500 & 0 & 1 & 1 & 0.59 & 0.49 \\
\hline Civic obligations index & 500 & 0 & 5 & 4 & 3.82 & 1.41 \\
\hline Should contact government & 500 & 0 & 1 & 1 & 0.66 & 0.48 \\
\hline Should contact media & 500 & 0 & 1 & 1 & 0.71 & 0.45 \\
\hline Should organize with others & 500 & 0 & 1 & 1 & 0.79 & 0.41 \\
\hline Should vote in elections & 500 & 0 & 1 & 1 & 0.87 & 0.34 \\
\hline Should pay taxes & 500 & 0 & 1 & 1 & 0.80 & 0.40 \\
\hline Anti-state actions index & 500 & 0 & 3 & 0 & 0.27 & 0.60 \\
\hline Occupy public building & 500 & 0 & 1 & 0 & 0.06 & 0.24 \\
\hline Road block & 500 & 0 & 1 & 0 & 0.09 & 0.29 \\
\hline Refuse taxes & 500 & 0 & 1 & 0 & 0.12 & 0.32 \\
\hline Collective action index & 500 & 0 & 6 & 1 & 1.48 & 1.56 \\
\hline Attended meeting (community) & 500 & 0 & 1 & 1 & 0.54 & 0.50 \\
\hline Volunteered in community & 500 & 0 & 1 & 0 & 0.26 & 0.44 \\
\hline Participated village governance & 500 & 0 & 1 & 0 & 0.31 & 0.46 \\
\hline Attended meeting (party) & 500 & 0 & 1 & 0 & 0.13 & 0.34 \\
\hline Joined CSO & 500 & 0 & 1 & 0 & 0.14 & 0.34 \\
\hline Joined party & 500 & 0 & 1 & 0 & 0.10 & 0.31 \\
\hline
\end{tabular}


Appendix C: Additional Results 


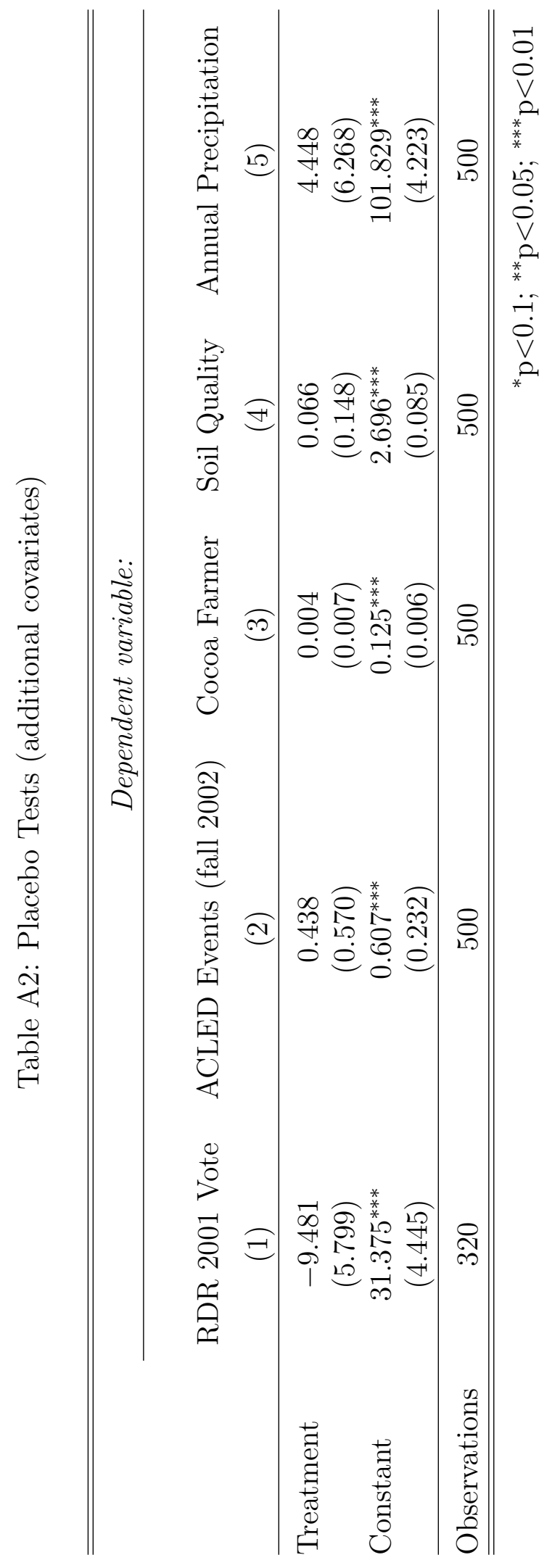


Table A3: Years Lived and Treatment Status by Ethnic Group

\begin{tabular}{lccc}
\hline \hline & \multicolumn{3}{c}{ Dependent variable: } \\
\cline { 2 - 4 } & Years Lived in Current Locality \\
& Krou & Mande & Akan \\
\hline Treatment & 4.928 & 0.797 & -0.622 \\
& $(3.175)$ & $(2.196)$ & $(2.570)$ \\
Constant & $24.964^{* * *}$ & $22.297^{* * *}$ & $20.261^{* * *}$ \\
& $(2.395)$ & $(1.605)$ & $(1.505)$ \\
\hline Observations & 130 & 159 & 105 \\
\hline \hline & \multicolumn{2}{c}{$\mathrm{p}<0.1 ;{ }^{* *} \mathrm{p}<0.05 ;{ }^{* * *} \mathrm{p}<0.01$}
\end{tabular}

Table A4: Constraining Sample Based on Years Lived in Current EA

\begin{tabular}{lcccccc}
\hline \hline & \multicolumn{5}{c}{ Dependent variable: } \\
\cline { 2 - 7 } & \multicolumn{5}{c}{ More than 8 years } & \multicolumn{3}{c}{ More than 16 years } \\
& SA Index & CO Index & AS Index & SA Index & CO Index & AS Index \\
\hline \multirow{2}{*}{ Treatment } & $-0.497^{* * *}$ & $-0.993^{* * *}$ & $0.179^{* *}$ & $-0.471^{* * *}$ & $-0.879^{* * *}$ & $0.163^{* *}$ \\
& $(0.140)$ & $(0.208)$ & $(0.077)$ & $(0.161)$ & $(0.235)$ & $(0.078)$ \\
Constant & $1.794^{* * *}$ & $4.251^{* * *}$ & $0.178^{* * *}$ & $1.786^{* * *}$ & $4.167^{* * *}$ & $0.193^{* * *}$ \\
& $(0.109)$ & $(0.096)$ & $(0.033)$ & $(0.124)$ & $(0.107)$ & $(0.039)$ \\
\hline Observations & 429 & 429 & 429 & 338 & 338 & 338 \\
\hline \hline
\end{tabular}



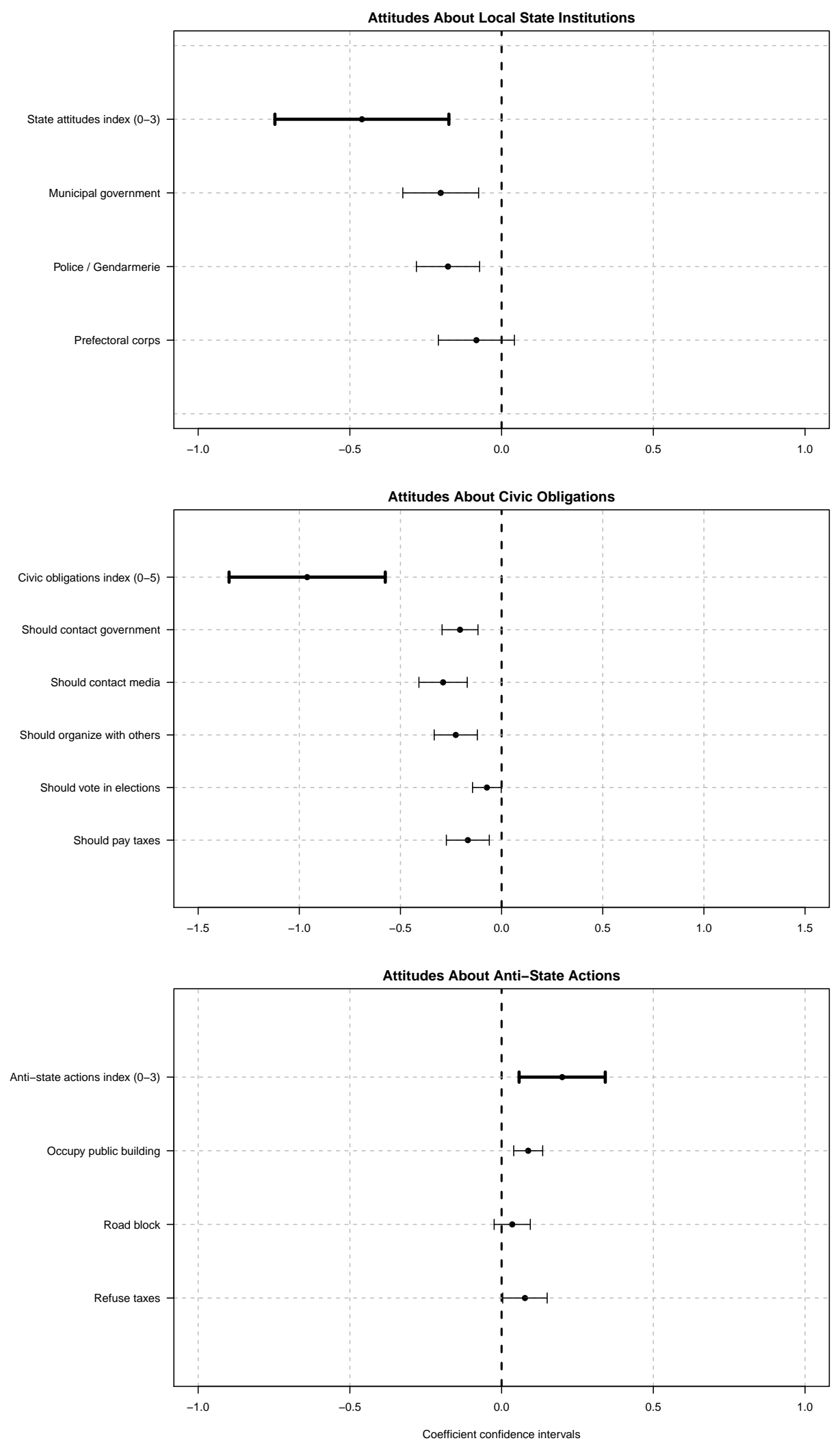

Figure A2: Main Results with Covariates Included (Age, Female, Christian, Mande, Education, Poverty, Years Lived) 

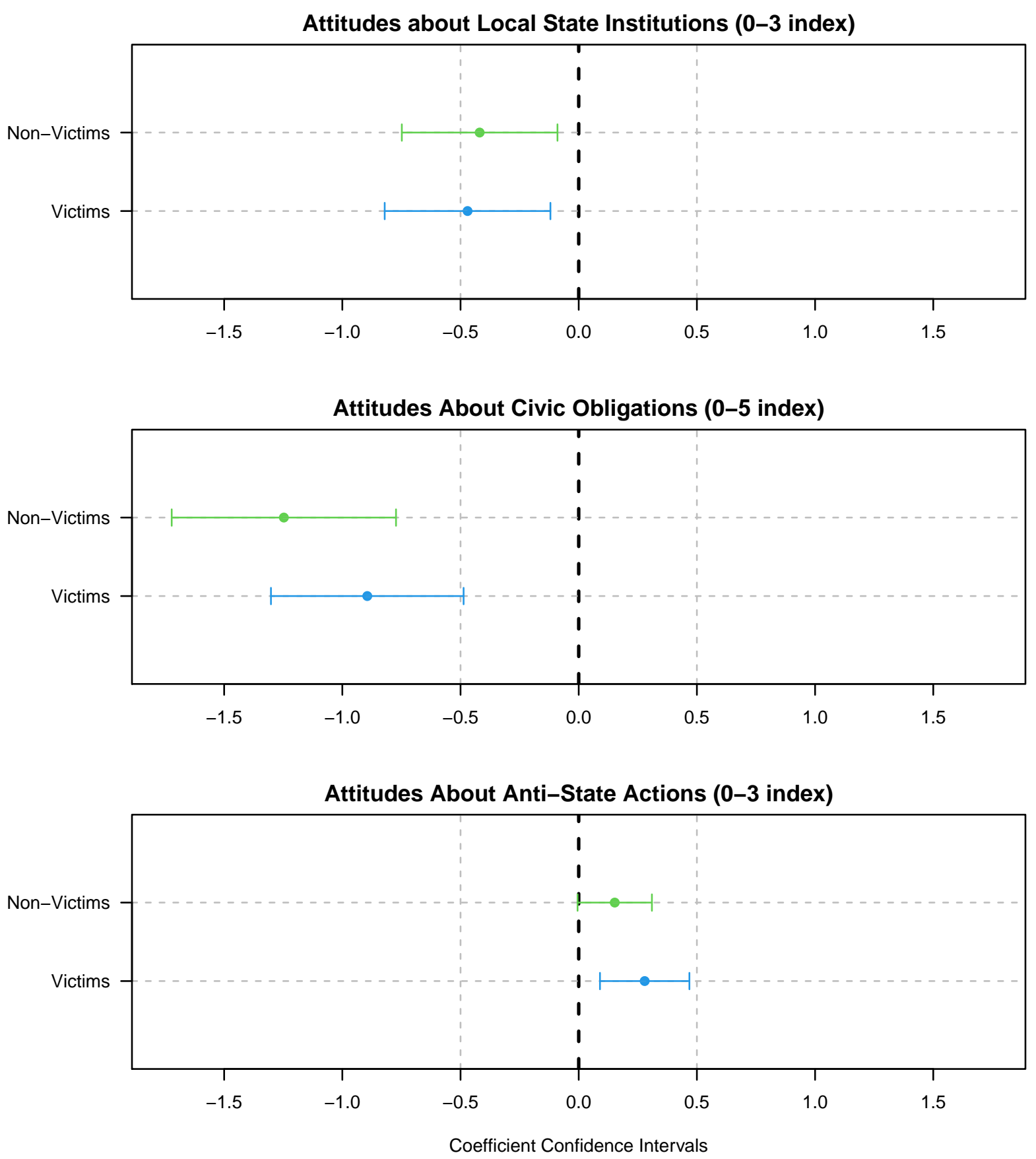

Figure A3: Heterogenous Effects by Victimization 
Table A5: Full Rebel Zone versus Border Rebel Zone

\begin{tabular}{rrrr}
\hline & Mean Rebel Zone & Mean Border Zone & t statistic \\
\hline Rebel Camp & 0.37 & 0.36 & 0.14 \\
Wartime Education & 0.65 & 0.67 & -0.64 \\
Wartime Health & 0.57 & 0.59 & -0.85 \\
Peacekeeping & 0.52 & 0.67 & -4.71 \\
Victim & 0.42 & 0.61 & -5.79 \\
Paid Taxes & 0.38 & 0.54 & -4.60 \\
\hline
\end{tabular}

Table A6: Rebel Zone versus Border Zone (Community Survey data from Martin 2021)

\begin{tabular}{rrrr}
\hline & Mean Rebel Zone & Mean Border Zone & t statistic \\
\hline Rebel Recruitment (Y/N) & 0.87 & 0.89 & -0.18 \\
Rebels Organized Meetings (Y/N) & 0.59 & 0.56 & 0.26 \\
No. of Rebel Goods Provided & 2.22 & 2.72 & -1.49 \\
Rebels Taxed (Y/N) & 0.90 & 0.94 & -0.78 \\
Elite Collaboration (Y/N) & 0.12 & 0.22 & -1.00 \\
\hline
\end{tabular}

Table A7: Benchmarking Against Extreme Lived Poverty

\begin{tabular}{|c|c|c|}
\hline & \multicolumn{2}{|c|}{ Dependent variable: } \\
\hline & SA Index & CO Index \\
\hline Treatment & $\begin{array}{c}-0.456^{* * *} \\
(0.145)\end{array}$ & $\begin{array}{c}-0.954^{* * *} \\
(0.192)\end{array}$ \\
\hline Extreme Poverty & $\begin{array}{c}-0.188^{*} \\
(0.113)\end{array}$ & $\begin{array}{c}-0.275^{* *} \\
(0.120)\end{array}$ \\
\hline Constant & $\begin{array}{c}1.896^{* * *} \\
(0.151)\end{array}$ & $\begin{array}{c}4.415^{* * *} \\
(0.137)\end{array}$ \\
\hline Observations & 500 & 500 \\
\hline $\begin{array}{l}\text { Notes: } \\
\mathrm{SA}=\text { State attitudes } \\
\mathrm{CO}=\text { Civic obligations }\end{array}$ & ${ }^{*} \mathrm{p}<0.1 ;{ }^{* *}$ & $05 ;{ }^{* * *} \mathrm{p}<0.01$ \\
\hline
\end{tabular}


Table A8: Placebo Tests (prewar covariates)

\section{Dependent variable:}

Social Assistance Informal Credit Willing to Adopt Social Capital Index

$(1)$

\begin{tabular}{lcccc}
\hline Treatment & 0.043 & 0.080 & -0.090 & 0.030 \\
Constant & $(0.041)$ & $(0.049)$ & $(0.057)$ & $(0.198)$ \\
& $0.937^{* * *}$ & $0.658^{* * *}$ & $0.586^{* * *}$ & $2.224^{* * *}$ \\
& $(0.037)$ & $(0.047)$ & $(0.046)$ & $(0.173)$ \\
\hline Observations & 500 & 500 & 500 & 500 \\
\hline \hline
\end{tabular}

Table A9: Constraining to near-ceasefire line areas, increments of 20km (SA Index)

\begin{tabular}{lccccc}
\hline \hline & \multicolumn{5}{c}{ Dependent variable: State attitudes index } \\
\cline { 2 - 6 } & $20 \mathrm{~km}$ & $40 \mathrm{~km}$ & $60 \mathrm{~km}$ & $80 \mathrm{~km}$ & $100 \mathrm{~km}$ \\
& $(1)$ & $(2)$ & $(3)$ & $(4)$ & $(5)$ \\
\hline Treatment & $-0.310^{*}$ & $-0.356^{* *}$ & $-0.386^{* * *}$ & $-0.408^{* * *}$ & $-0.405^{* * *}$ \\
& $(0.161)$ & $(0.140)$ & $(0.135)$ & $(0.116)$ & $(0.107)$ \\
Constant & $1.633^{* * *}$ & $1.700^{* * *}$ & $1.700^{* * *}$ & $1.722^{* * *}$ & $1.723^{* * *}$ \\
& $(0.124)$ & $(0.109)$ & $(0.107)$ & $(0.085)$ & $(0.076)$ \\
\hline Observations & 220 & 300 & 330 & 390 & 440 \\
\hline \hline
\end{tabular}


Table A10: Constraining to near-ceasefire line areas, increments of 20km (CO Index)

\begin{tabular}{lccccc}
\hline \hline & \multicolumn{5}{c}{ Dependent variable: Civic obligations index } \\
\cline { 2 - 6 } & $20 \mathrm{~km}$ & $40 \mathrm{~km}$ & $60 \mathrm{~km}$ & $80 \mathrm{~km}$ & $100 \mathrm{~km}$ \\
& $(1)$ & $(2)$ & $(3)$ & $(4)$ & $(5)$ \\
\hline Treatment & $-0.721^{* * *}$ & $-0.847^{* * *}$ & $-0.918^{* * *}$ & $-0.943^{* * *}$ & $-1.000^{* * *}$ \\
& $(0.195)$ & $(0.161)$ & $(0.158)$ & $(0.137)$ & $(0.128)$ \\
Constant & $4.167^{* * *}$ & $4.242^{* * *}$ & $4.242^{* * *}$ & $4.267^{* * *}$ & $4.282^{* * *}$ \\
& $(0.150)$ & $(0.125)$ & $(0.126)$ & $(0.100)$ & $(0.090)$ \\
\hline Observations & 220 & 300 & 330 & 390 & 440 \\
\hline \hline
\end{tabular}

Table A11: Constraining to near-ceasefire line areas, increments of 20km (AS Index)

\begin{tabular}{lccccc}
\hline \hline & \multicolumn{5}{c}{ Dependent variable: Anti-state attitudes index } \\
\cline { 2 - 6 } & $20 \mathrm{~km}$ & $40 \mathrm{~km}$ & $60 \mathrm{~km}$ & $80 \mathrm{~km}$ & $100 \mathrm{~km}$ \\
& $(1)$ & $(2)$ & $(3)$ & $(4)$ & $(5)$ \\
\hline Treatment & $0.226^{* * *}$ & $0.247^{* * *}$ & $0.235^{* * *}$ & $0.171^{* * *}$ & $0.195^{* * *}$ \\
Constant & $(0.077)$ & $(0.071)$ & $(0.068)$ & $(0.060)$ & $(0.059)$ \\
& 0.089 & $0.108^{* *}$ & $0.108^{* *}$ & $0.172^{* * *}$ & $0.186^{* * *}$ \\
Observations & $(0.059)$ & $(0.055)$ & $(0.054)$ & $(0.044)$ & $(0.042)$ \\
\hline \hline
\end{tabular}


Table A12: Placebo Borders (25km intervals)

\begin{tabular}{|c|c|c|c|}
\hline & \multicolumn{3}{|c|}{ Dependent variable: } \\
\hline & \multicolumn{3}{|c|}{ State Attitudes Index } \\
\hline & $(1)$ & $(2)$ & $(3)$ \\
\hline Placebo Treatment (25km) & $\begin{array}{c}-0.285^{*} \\
(0.151)\end{array}$ & & \\
\hline Placebo Treatment (50km) & & $\begin{array}{c}-0.235 \\
(0.208)\end{array}$ & \\
\hline Placebo Treatment $(75 \mathrm{~km})$ & & & $\begin{array}{l}-0.136 \\
(0.365)\end{array}$ \\
\hline Constant & $\begin{array}{c}1.208^{* * *} \\
(0.254)\end{array}$ & $\begin{array}{c}1.123^{* * *} \\
(0.257) \\
\end{array}$ & $\begin{array}{c}0.992^{* * *} \\
(0.227) \\
\end{array}$ \\
\hline Observations & 500 & 500 & 500 \\
\hline
\end{tabular}

Table A13: Political Attitudes and Distance from Ceasefire Line

\begin{tabular}{lcccccc}
\hline \hline & \multicolumn{5}{c}{ Dependent variable: } \\
\cline { 2 - 7 } & \multicolumn{3}{c}{ Rebel Side } & \multicolumn{3}{c}{ Government Side } \\
& SA & CO & AS & SA & CO & AS \\
\hline North-South Distance $(\mathrm{km})$ & -0.001 & $-0.009^{* *}$ & 0.005 & 0.003 & -0.001 & $0.001^{*}$ \\
& $(0.003)$ & $(0.004)$ & $(0.004)$ & $(0.002)$ & $(0.002)$ & $(0.001)$ \\
Constant & $1.350^{* * *}$ & $3.485^{* * *}$ & $0.269^{* * *}$ & $1.592^{* * *}$ & $4.257^{* * *}$ & $0.127^{* * *}$ \\
& $(0.102)$ & $(0.183)$ & $(0.094)$ & $(0.196)$ & $(0.164)$ & $(0.043)$ \\
\hline Observations & 220 & 220 & 220 & 280 & 280 & 280 \\
\hline \hline
\end{tabular}


Table A14: Region Fixed Effects (OLS)

\begin{tabular}{|c|c|c|c|}
\hline & \multicolumn{3}{|c|}{ Dependent variable: } \\
\hline & SA Index & CO Index & AS Index \\
\hline Treatment & $\begin{array}{c}-1.314^{* * *} \\
(0.285)\end{array}$ & $\begin{array}{c}-1.500^{* * *} \\
(0.252)\end{array}$ & $\begin{array}{c}0.243^{* *} \\
(0.115)\end{array}$ \\
\hline Constant & $\begin{array}{c}2.600^{\text {*** }} \\
(0.252)\end{array}$ & $\begin{array}{c}4.600^{* * *} \\
(0.040)\end{array}$ & $\begin{array}{c}0.100 \\
(0.093)\end{array}$ \\
\hline Observations & 500 & 500 & 500 \\
\hline
\end{tabular}

Table A15: Enumeration Area Level Averages

\begin{tabular}{|c|c|c|c|}
\hline & \multicolumn{3}{|c|}{ Dependent variable: } \\
\hline & $\begin{array}{l}\text { SA Index } \\
(1)\end{array}$ & $\begin{array}{c}\text { CO Index } \\
(2)\end{array}$ & $\begin{array}{c}\text { AS Index } \\
(3)\end{array}$ \\
\hline Treatment & $\begin{array}{c}-0.460^{* * *} \\
(0.155)\end{array}$ & $\begin{array}{c}-0.961^{* * *} \\
(0.192)\end{array}$ & $\begin{array}{c}0.200^{* * *} \\
(0.069)\end{array}$ \\
\hline Constant & $\begin{array}{c}1.779^{* * *} \\
(0.103)\end{array}$ & $\begin{array}{c}4.243^{* * *} \\
(0.127)\end{array}$ & $\begin{array}{c}0.182^{* * *} \\
(0.046)\end{array}$ \\
\hline Observations & 50 & 50 & 50 \\
\hline $\begin{array}{l}\text { Notes: } \\
\text { SA = State attitudes; } \\
\text { CO = Civic obligations; } \\
\text { AS = Anti-state attitudes }\end{array}$ & \multicolumn{3}{|c|}{${ }^{*} \mathrm{p}<0.1 ;{ }^{* *} \mathrm{p}<0.05 ;{ }^{* * *} \mathrm{p}<0.01$} \\
\hline
\end{tabular}


Table A16: Controlling for Peacekeeping and NGO presence

\begin{tabular}{|c|c|c|c|}
\hline & \multicolumn{3}{|c|}{ Dependent variable: } \\
\hline & SA Index & CO Index & AS Index \\
\hline Treatment & $\begin{array}{c}-0.463^{* * *} \\
(0.126)\end{array}$ & $\begin{array}{c}-0.949^{* * *} \\
(0.209)\end{array}$ & $\begin{array}{c}0.228^{* * *} \\
(0.067)\end{array}$ \\
\hline Age & $\begin{array}{c}0.001 \\
(0.004)\end{array}$ & $\begin{array}{c}-0.008^{*} \\
(0.005)\end{array}$ & $\begin{array}{l}-0.001 \\
(0.002)\end{array}$ \\
\hline Female & $\begin{array}{l}-0.141 \\
(0.101)\end{array}$ & $\begin{array}{l}-0.127 \\
(0.113)\end{array}$ & $\begin{array}{c}0.040 \\
(0.053)\end{array}$ \\
\hline Christian & $\begin{array}{c}0.033 \\
(0.108)\end{array}$ & $\begin{array}{l}0.364^{* *} \\
(0.145)\end{array}$ & $\begin{array}{c}-0.152^{* * *} \\
(0.049)\end{array}$ \\
\hline Mande & $\begin{array}{c}0.099 \\
(0.120)\end{array}$ & $\begin{array}{l}-0.087 \\
(0.158)\end{array}$ & $\begin{array}{c}-0.165^{* * *} \\
(0.062)\end{array}$ \\
\hline Education & $\begin{array}{c}0.409^{* * *} \\
(0.097)\end{array}$ & $\begin{array}{c}0.069 \\
(0.141)\end{array}$ & $\begin{array}{c}0.030 \\
(0.047)\end{array}$ \\
\hline Poverty & $\begin{array}{c}-0.682^{* *} \\
(0.323)\end{array}$ & $\begin{array}{c}0.006 \\
(0.487)\end{array}$ & $\begin{array}{l}-0.179 \\
(0.166)\end{array}$ \\
\hline Years Lived & $\begin{array}{l}-0.001 \\
(0.004)\end{array}$ & $\begin{array}{c}0.002 \\
(0.006)\end{array}$ & $\begin{array}{l}-0.001 \\
(0.003)\end{array}$ \\
\hline Peacekeeping & $\begin{array}{l}0.221^{*} \\
(0.116)\end{array}$ & $\begin{array}{l}-0.093 \\
(0.179)\end{array}$ & $\begin{array}{l}-0.027 \\
(0.065)\end{array}$ \\
\hline NGO & $\begin{array}{c}0.309^{* * *} \\
(0.112)\end{array}$ & $\begin{array}{c}0.169 \\
(0.145)\end{array}$ & $\begin{array}{l}0.124^{* *} \\
(0.048)\end{array}$ \\
\hline Constant & $\begin{array}{c}1.419^{* * *} \\
(0.292)\end{array}$ & $\begin{array}{c}4.262^{* * *} \\
(0.427)\end{array}$ & $\begin{array}{l}0.355^{* *} \\
(0.177)\end{array}$ \\
\hline Observations & 500 & 500 & 500 \\
\hline
\end{tabular}


Table A17: Wartime Collective Action Analyses

Dependent variable:

\begin{tabular}{lccccc} 
& Wartime CA & Current CA & SA Index & CO Index & AS Index \\
\hline Treatment & $0.297^{* *}$ & 0.170 & $-0.479^{* * *}$ & $-0.912^{* * *}$ & $0.210^{* * *}$ \\
& $(0.150)$ & $(0.128)$ & $(0.135)$ & $(0.208)$ & $(0.069)$ \\
Wartime Collective Action & & $0.696^{* * *}$ & -0.008 & $-0.157^{* * *}$ & $0.036^{*}$ \\
& & $(0.041)$ & $(0.049)$ & $(0.053)$ & $(0.020)$ \\
Constant & -0.030 & $0.949^{* * *}$ & $1.658^{* * *}$ & $4.382^{* * *}$ & $0.454^{* * *}$ \\
& $(0.408)$ & $(0.312)$ & $(0.303)$ & $(0.406)$ & $(0.167)$ \\
\hline Additional Covariates & Yes & Yes & Yes & Yes & Yes \\
\hline Observations & 500 & 500 & 500 & 500 & 500 \\
\hline CA $=$ collective action index & & & \multicolumn{2}{c}{${ }^{*} \mathrm{p}<0.1 ;{ }^{* *} \mathrm{p}<0.05 ;{ }^{* * *} \mathrm{p}<0.01$}
\end{tabular}


Table A18: Within-Rebel Zone Comparison

\begin{tabular}{|c|c|c|c|}
\hline & \multicolumn{3}{|c|}{ Dependent variable: } \\
\hline & SA Index & CO Index & AS Index \\
\hline Wartime Services & $\begin{array}{l}0.103^{* *} \\
(0.051)\end{array}$ & $\begin{array}{c}0.184^{* * *} \\
(0.057)\end{array}$ & $\begin{array}{l}-0.004 \\
(0.026)\end{array}$ \\
\hline Age & $\begin{array}{l}0.003 \\
(0.004)\end{array}$ & $\begin{array}{l}-0.004 \\
(0.005)\end{array}$ & $\begin{array}{c}-0.006^{* *} \\
(0.002)\end{array}$ \\
\hline Female & $\begin{array}{l}-0.078 \\
(0.082)\end{array}$ & $\begin{array}{c}-0.196^{* *} \\
(0.094)\end{array}$ & $\begin{array}{l}-0.037 \\
(0.054)\end{array}$ \\
\hline Christian & $\begin{array}{c}0.030 \\
(0.111)\end{array}$ & $\begin{array}{c}0.350^{* * *} \\
(0.125)\end{array}$ & $\begin{array}{l}-0.096 \\
(0.063)\end{array}$ \\
\hline Nordiste & $\begin{array}{l}0.289^{* *} \\
(0.130)\end{array}$ & $\begin{array}{c}0.172 \\
(0.162)\end{array}$ & $\begin{array}{c}-0.052 \\
(0.064)\end{array}$ \\
\hline Education 2002 & $\begin{array}{c}0.376 \\
(0.439)\end{array}$ & $\begin{array}{c}-1.679^{* * *} \\
(0.647)\end{array}$ & $\begin{array}{c}0.353 \\
(0.215)\end{array}$ \\
\hline Poverty 2002 & $\begin{array}{l}-0.358 \\
(0.220)\end{array}$ & $\begin{array}{c}-0.572^{*} \\
(0.306)\end{array}$ & $\begin{array}{c}0.194 \\
(0.119)\end{array}$ \\
\hline Social Capital 2002 & $\begin{array}{l}-0.465 \\
(0.435)\end{array}$ & $\begin{array}{c}0.528 \\
(0.609)\end{array}$ & $\begin{array}{l}-0.065 \\
(0.227)\end{array}$ \\
\hline Years Lived & $\begin{array}{l}-0.002 \\
(0.003)\end{array}$ & $\begin{array}{c}0.001 \\
(0.004)\end{array}$ & $\begin{array}{l}0.0001 \\
(0.002)\end{array}$ \\
\hline Permanent Camp & $\begin{array}{l}-0.070 \\
(0.095)\end{array}$ & $\begin{array}{l}0.265^{* *} \\
(0.129)\end{array}$ & $\begin{array}{c}0.097 \\
(0.087)\end{array}$ \\
\hline Peacekeeping & $\begin{array}{c}-0.348^{* * *} \\
(0.125)\end{array}$ & $\begin{array}{l}0.195 \\
(0.156)\end{array}$ & $\begin{array}{l}-0.059 \\
(0.077)\end{array}$ \\
\hline Victim & $\begin{array}{c}-0.218^{* *} \\
(0.108)\end{array}$ & $\begin{array}{l}0.362^{* *} \\
(0.145)\end{array}$ & $\begin{array}{l}0.165^{* *} \\
(0.069)\end{array}$ \\
\hline Paid Tax & $\begin{array}{c}0.086 \\
(0.104)\end{array}$ & $\begin{array}{c}0.106 \\
(0.136)\end{array}$ & $\begin{array}{c}0.027 \\
(0.072)\end{array}$ \\
\hline Wartime Collective Action & $\begin{array}{l}0.071^{*} \\
(0.038)\end{array}$ & $\begin{array}{l}-0.003 \\
(0.041)\end{array}$ & $\begin{array}{l}-0.022 \\
(0.021)\end{array}$ \\
\hline Urban & $\begin{array}{l}0.273^{* *} \\
(0.117)\end{array}$ & $\begin{array}{c}0.105 \\
(0.152)\end{array}$ & $\begin{array}{l}-0.051 \\
(0.083)\end{array}$ \\
\hline Constant & $\begin{array}{c}2.085^{* * *} \\
(0.771)\end{array}$ & $\begin{array}{l}3.178^{* *} \\
(1.315)\end{array}$ & $\begin{array}{c}0.327 \\
(0.448)\end{array}$ \\
\hline Observations & 900 & 900 & 900 \\
\hline
\end{tabular}

